\title{
Absorbing aerosol in the troposphere of the Western Arctic during the 2008 ARCTAS/ARCPAC airborne field campaigns
}

\author{
C. S. McNaughton ${ }^{1}$, A. D. Clarke ${ }^{1}$, S. Freitag ${ }^{1}$, V. N. Kapustin ${ }^{1}$, Y. Kondo ${ }^{2}$, N. Moteki ${ }^{2}$, L. Sahu ${ }^{2}$, N. Takegawa ${ }^{2}$, \\ J. P. Schwarz ${ }^{3}$, J. R. Spackman ${ }^{3}$, L. Watts ${ }^{3}$, G. Diskin ${ }^{4}$, J. Podolske ${ }^{5}$, J. S. Holloway ${ }^{3}$, A. Wisthaler ${ }^{6}$, T. Mikoviny ${ }^{6}$, \\ J. de Gouw ${ }^{3}$, C. Warneke ${ }^{3,7}$, J. Jimenez ${ }^{7}$, M. Cubison ${ }^{7}$, S. G. Howell ${ }^{1}$, A. Middlebrook ${ }^{3}$, R. Bahreini ${ }^{3}$,

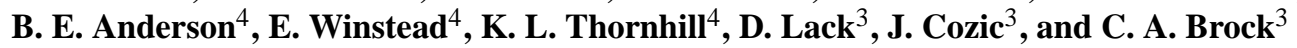 \\ ${ }^{1}$ School of Ocean and Earth Science and Technology, University of Hawaii, Honolulu, HI, USA \\ ${ }^{2}$ Research Center for Advanced Science and Technology, University of Tokyo, Tokyo, Japan \\ ${ }^{3}$ Chemical Sciences Division, NOAA Earth System Research Laboratory, Boulder, CO, USA \\ ${ }^{4}$ NASA Langley Research Center, Hampton, VA, USA \\ ${ }^{5}$ NASA Ames Research Center, Moffett Field, CA, USA \\ ${ }^{6}$ Institute of Ion Physics and Applied Physics, University of Innsbruck, Innsbruck, Austria \\ ${ }^{7}$ Cooperative Institute for Research in Environmental Sciences (CIRES) University of Colorado, Boulder, CO, USA
}

Received: 6 November 2010 - Published in Atmos. Chem. Phys. Discuss.: 19 January 2011

Revised: 23 June 2011 - Accepted: 6 July 2011 - Published: 1 August 2011

\begin{abstract}
In the spring of 2008 NASA and NOAA funded the ARCTAS and ARCPAC field campaigns as contributions to POLARCAT, a core IPY activity. During the campaigns the NASA DC-8, P-3B and NOAA WP-3D aircraft conducted over $160 \mathrm{~h}$ of in-situ sampling between 0.1 and $12 \mathrm{~km}$ throughout the Western Arctic north of $55^{\circ} \mathrm{N}$ (i.e. Alaska to Greenland). All aircraft were equipped with multiple wavelength measurements of aerosol optics, trace gas and aerosol chemistry measurements, as well as direct measurements of the aerosol size distributions and black carbon mass. Late April of 2008 proved to be exceptional in terms of Asian biomass burning emissions transported to the Western Arctic. Though these smoke plumes account for only $11-14 \%$ of the samples within the Western Arctic domain, they account for $42-47 \%$ of the total burden of black carbon. Dust was also commonly observed but only contributes to $4-12 \%$ and $3-8 \%$ of total light absorption at 470 and $530 \mathrm{~nm}$ wavelengths above $6 \mathrm{~km}$. Below $6 \mathrm{~km}$, light absorption by carbonaceous aerosol derived from urban/industrial and biomass burning emissions account for $97-99 \%$ of total light absorption by aerosol. Stratifying the data to reduce the influence of dust allows us to determine mass absorption efficiencies for black carbon of $11.2 \pm 0.8$, $9.5 \pm 0.6$ and $7.4 \pm 0.7 \mathrm{~m}^{2} \mathrm{~g}^{-1}$ at 470,530 and $660 \mathrm{~nm}$ wave-
\end{abstract}

Correspondence to: C. S. McNaughton (csmcnaug@hawaii.edu) lengths. These estimates are consistent with $35-80 \%$ enhancements in $530 \mathrm{~nm}$ absorption due to clear or slightly absorbing coatings of pure black carbon particulate. Assuming a $1 / \lambda$ wavelength dependence for $\mathrm{BC}$ absorption, and assuming that refractory aerosol $\left(420^{\circ} \mathrm{C}, \tau=0.1 \mathrm{~s}\right)$ in lowdust samples is dominated by brown carbon, we derive mass absorption efficiencies for brown carbon of $0.83 \pm 0.15$ and $0.27 \pm 0.08 \mathrm{~m}^{2} \mathrm{~g}^{-1}$ at 470 and $530 \mathrm{~nm}$ wavelengths. Estimates for the mass absorption efficiencies of Asian dust are $0.034 \mathrm{~m}^{2} \mathrm{~g}^{-1}$ and $0.017 \mathrm{~m}^{2} \mathrm{~g}^{-1}$. However the absorption efficiency estimates for dust are highly uncertain due to the limitations imposed by PSAP instrument noise. In-situ ARCTAS/ARCPAC measurements during the IPY provide valuable constraints for absorbing aerosol over the Western Arctic, species which are currently poorly simulated over a region that is critically under-sampled.

\section{Introduction}

The cryosphere, perhaps more than any other domain, is experiencing a profound, perhaps millennia-long (Solomon et al., 2009), transformation that is in part a result of anthropogenic induced climate change (ACIA, 2004; IPCC, 2007). Yet in many respects, the Arctic atmosphere remains critically undersampled. Ground based measurements of Arctic aerosol have been made since the early 1980's (Quinn et

Published by Copernicus Publications on behalf of the European Geosciences Union. 
al., 2007) but coverage is sparse and limited to the surface boundary layer. Ground-based remote sensing using sunphotometers (Bokoye et al., 2002; Tomasi et al., 2007) or lidar (Bourdages et al., 2009; Ishii et al., 1999; Leaitch et al., 1989), also have sparse coverage and retrievals complicated by seasonally persistent cloud cover. Satellite retrievals at high latitudes are also complicated by cloud cover and a typically bright target surface (i.e. snow and ice). Although airborne campaigns have provided in-situ measurements throughout the depth of the Arctic troposphere (Clarke et al., 1984; Rogers et al., 2001; Scheuer et al., 2003; Yamanouchi et al., 2005) their temporal and spatial coverage limits the extent to which they can be used to constrain stateof-the-art climate model simulations (e.g. Koch et al., 2009).

Arctic Haze is a winter/spring accumulation of aerosol and trace gases in the Arctic atmosphere thought to be largely of anthropogenic origin (Shaw, 1995). In-situ snow sampling during the International Polar Year (IPY) confirm that urban industrial emissions of black carbon are common in the Arctic snowpack and that biomass burning aerosol is a dominant signal in Spring (Hegg et al., 2010). Potential increases in wildfire frequency and intensity in a warmer climate (Stocks et al., 1998; Westerling et al., 2006) have led to renewed interest in the role of fire in the Earth's climate system (Fromm et al., 2010). However, reliable estimates of plume injections heights, required for accurate simulation of their long-range transport and radiative effects, have only recently become available on global scales (Guan et al., 2010).

The radiative effects of the absorbing components of haze are enhanced over a reflective surface and, unlike snowfree regions, the radiative effects continue by reducing snow albedo after their removal to the snow pack (Clarke and Noone, 1985). Reductions in snow and ice albedo is of particular concern because of its positive feedback on melting of seasonal snow cover at mid-latitudes (Flanner et al., 2009), permanent snow and ice at high altitude (Menon et al., 2010; Xu et al., 2009) and in the polar regions (Hansen and Nazarenko, 2004).

In the spring of 2008 NASA-funded the Arctic Research of the Composition of the Troposphere from Aircraft and Satellites (ARCTAS) field campaign (Jacob et al., 2010), in conjunction with the NOAA-funded Aerosol, Radiation, and Cloud Processes affecting Arctic Climate (ARCPAC) (Brock et al., 2010). These experiments were US contributions to POLARCAT, a core International Polar Year (IPY) activity. Here we summarize measurements of absorbing aerosol in the troposphere of the Western Arctic including black carbon $(\mathrm{BC})$, brown carbon $(\mathrm{BrC})$ and mineral dust. In this paper we use gas-phase tracers and aerosol composition to discriminate absorbing aerosol of urban/industrial origin from absorbing aerosol generated from biomass burning. This method of stratification is then applied to simultaneous measurements of carbon monoxide, accumulation mode black carbon mass and aerosol optical properties. This enables the determination of mass absorption efficiencies (MAE) for these aerosol types over the Western Arctic and leads to a discussion of their relative contributions to total light absorption by aerosol sampled in the troposphere over the Western Arctic in the Spring of 2008.

\section{Instrumentation}

Three single particle soot absorption photometers (SP2) (Baumgardner et al., 2004; Stephens et al., 2003; Subramanian et al., 2010) were deployed on board NASA and NOAA research aircraft during the ARCTAS/ARCPAC airborne field campaigns. The DC-8 instrument (Moteki and Kondo, 2007; Moteki et al., 2007) was operated by a team from the University of Tokyo (Kondo et al.), the P-3B instrument was operated by a team from the University of Hawaii (Clarke et al.) and the NOAA WP-3D instrument (Schwarz et al., 2006) was operated by a team from NOAA's Aeronomy Lab (Fahey et al.). Teams from the University of ColoradoBoulder (DC-8, Jimenez et al.), the University of Hawaii (P-3B, Howell) and NOAA's ESRL CSD (WP-3D, Middlebrook et al.) measured submicrometer non-refractory aerosol chemistry $\left(\mathrm{NH}_{4}^{+}, \mathrm{NO}_{3}^{-}, \mathrm{SO}_{4}^{2-}, \mathrm{NR} \mathrm{Cl}^{-}\right.$, and organics) using high-resolution time-of-flight aerosol mass spectrometry (HR-ToF-AMS) (Canagaratna et al., 2007; DeCarlo et al., 2006). Carbon monoxide is measured on board the DC-8, P-3B and WP-3D by teams from NASA Langley (Diskin), NASA Ames (Podolske) and NOAA ESRL CSD (Holloway) research centers. Gas-phase measurements of acetonitrile were measured on board the DC- 8 by the University of Innsbruck (Wisthaler et al.) (Lindinger et al., 1998; Sprung et al., 2001) and aboard the WP-3D by a team from NOAA's ESRL CSD (de Gouw et al.) (de Gouw and Warneke, 2007). Acetonitrile was not measured on board the NASA P-3B.

Total and submicrometer aerosol light scattering were measured onboard the DC- 8 by the NASA Langley Research Center (Anderson et al.) and onboard the P-3B by the University of Hawaii (Clarke et al.) using TSI 3- $\lambda$ nephelometers corrected according to Anderson and Ogren (1998). Light absorption coefficients were measured aboard the NASA aircraft using 3- $\lambda$ Radiance Research particle soot absorption photometers (PSAP's). The PSAP absorption measurements have been corrected using an updated algorithm (Virkkula, 2010), however levels of instrument noise remain $\sim 0.5 \mathrm{Mm}^{-1}$ for a $240-300$ s sample average, comparable to values reported previously (Anderson et al., 2003; McNaughton et al., 2009). Submicrometer aerosol extinction and absorption were measured on board the WP-3D by a team from the NOAA ESRL (Brock et al., and Lack) using a photo-acoustic method (Slowik et al., 2007) and a $532 \mathrm{~nm}$ Radiance Research PSAP also corrected according to Virkkula et al. (2010).

Aerosol size distributions were measured on board the NASA DC-8 using a TSI DMA ${ }^{1}\left(d_{\mathrm{m}}=0.01-0.50 \mu \mathrm{m}\right)$, a

\footnotetext{
${ }^{1}$ Differential Mobility Analyzer
} 
Droplet Measurement Technologies UHSAS ${ }^{2}\left(d_{\mathrm{oe}}=0.08\right.$ $3.0 \mu \mathrm{m})$ and a TSI $\operatorname{APS}^{3}\left(d_{\mathrm{ae}}=0.78-20.0 \mu \mathrm{m}\right)$. Aerosol size distributions were measured on board the NASA P-3B using two custom DMA's (TDMA $d_{\mathrm{m}}=0.01-0.20 \mu \mathrm{m}$; LDMA $\left.d_{\mathrm{m}}=0.010-0.50 \mu \mathrm{m}\right)$, an optical particle counter $\left(d_{\mathrm{oe}}=0.15-\right.$ $8.0 \mu \mathrm{m})$ and a TSI APS $\left(d_{\mathrm{ae}}=0.78-20.0 \mu \mathrm{m}\right)($ McNaughton et al., 2009). The DC-8 solid diffuser inlet (UH-SDI) is that described in McNaughton et al. (2007), whereas the P-3B employed a newly fabricated inlet with characteristics identical to those of the original UH-SDI. Aerosol size distributions between 0.004 and $7.0 \mu \mathrm{m}$ were measured on board the NOAA WP-3D using a 5-channel condensation particle counter (CPC) (Brock et al., 2000) and optical particle counters (Brock et al., 2008) operating behind a low-turbulence inlet (Huebert et al., 2004b; Wilson et al., 2004).

\section{Results}

The NASA DC-8 and P-3B sampled airmasses over the Western Arctic between 31 March and 19 April 2008 and include three sorties from Alaska to Greenland with one DC-8 flight via the North Pole (Fig. 1). The NOAA WP-3D flights occurred between 11 and 24 April 2008, and concentrated on sampling airmasses over Alaska and the nearby Arctic Ocean. All three platforms encountered airmasses containing anthropogenic urban/industrial emissions, biomass burning and mineral dust but with differing frequencies and intensities.

Mean vertical profiles of $\mathrm{CO}$, dry aerosol extinction and accumulation mode $(\sim 0.09-0.90 \mu \mathrm{m})$ black carbon mass for each of the three airborne platforms are summarized in Fig. 2. Surface-based measurements of $\mathrm{CO}$ and total and submicrometer dry aerosol extinction at NOAA's Earth System Research Laboratory (ESRL) Barrow, Alaska site (Barrow) for April 2008 (Sharma et al., 2006), as well black carbon measurements at Environment Canada's Alert Weather Station (Alert) (Gong et al., 2010) are included for comparison.

The first panel of Fig. 2 illustrates that near-surface mean $\mathrm{CO}$ measured aboard all three aircraft are consistent with the observations at Barrow. Standard deviations of $\mathrm{CO}$ for the NASA DC-8 and WP-3D are plotted as dashed lines in the first panel of Fig. 2. CO measurements aboard both NASA platforms have coefficients of variation (standard deviation divided by the mean) below $\sim 10 \%$ at altitudes below $\sim 3 \mathrm{~km}$ increasing to $10-20 \%$ between 4 and $8 \mathrm{~km}$ and $>20 \%$ above $8 \mathrm{~km}$. With the exception of an intense plume sampled just below $4 \mathrm{~km}$ on 19 April, the NASA data indicate the average profiles are relatively uniform below $\sim 6 \mathrm{~km}$. Above $6 \mathrm{~km} \mathrm{CO}$ concentrations begin to steadily decrease due to dilution after mixing high-CO tropospheric air with low-CO air from the stratosphere. In contrast, $\mathrm{CO}$ measured aboard the NOAA

\footnotetext{
${ }^{2}$ Ultra-High Sensitivity Aerosol Spectrometer

3 Aerodynamic Particle Sizer
}

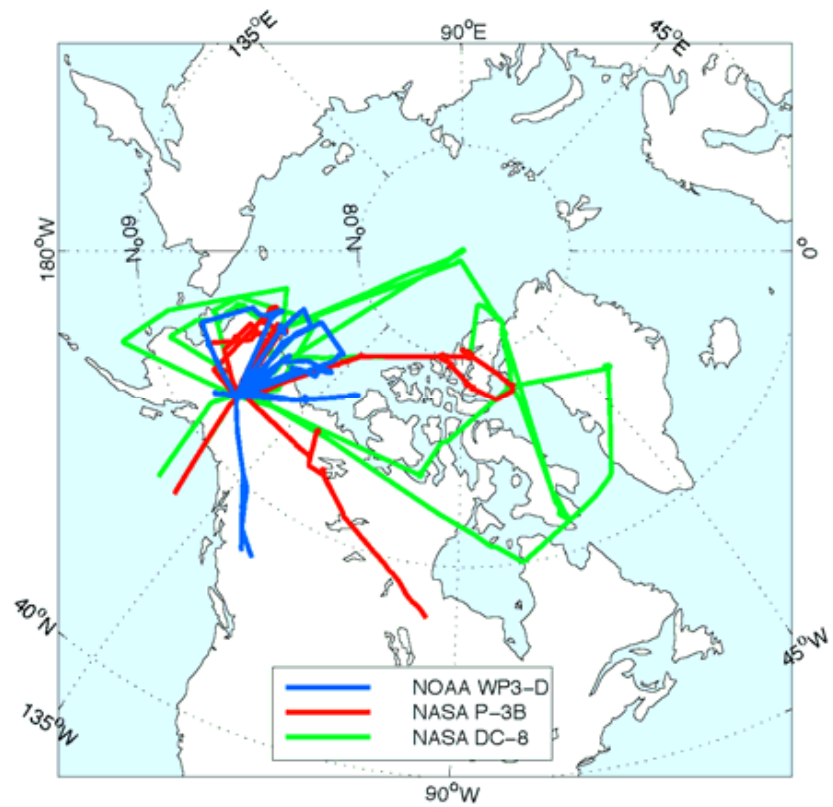

Fig. 1. Flight tracks north of $55^{\circ} \mathrm{N}$ for the NASA DC-8 (green), NASA P-3B (red) during ARCTAS and the NOAA WP-3D (blue) during ARCPAC.

WP-3D are elevated aloft as a result of sampling intense biomass burning plumes over Alaska in late April (Warneke et al., 2009). Coefficients of variation for $\mathrm{CO}$ from the surface to $7 \mathrm{~km}$ are $\sim 10-25 \%$ and illustrate the effect that intense episodic plumes have on the composition of the middle and lower troposphere.

The profiles of total and submicrometer dry aerosol extinction peak in the middle troposphere and illustrate the ubiquitous presence of mineral dust in the troposphere of the Western Arctic. Measurements of submicrometer extinction aboard the NOAA WP-3D illustrate the substantial variability in campaign-averaged extinction. Again, coefficients of variation generally increase from values $\sim 50 \%$ near the surface and peak at $3-6 \mathrm{~km}$ where they can reach values $>200 \%$. These differences result from spatial and temporal heterogeneity of aerosol found in pollution and biomass burning plumes, as well as differences in the sampling strategies employed by each aircraft. The differences cannot be attributed to differences in inter-platform instrument accuracy nor inlet performance as 4 pairs of intercomparison flights over a range of altitudes indicate instrument differences of generally less than $10 \%$.

The important role of combustion-derived aerosol is illustrated by the vertical profiles of BC mass in Fig. 2 . The mean $\mathrm{BC}$ profiles peak in the middle troposphere with concentrations between $200-300 \mathrm{ng} \mathrm{s} \mathrm{m}^{-3}(T=273.15 \mathrm{~K}$, $P=1013.25 \mathrm{mb}$ ), but are reduced by a factor of four to $\sim 50 \mathrm{ng} \mathrm{s} \mathrm{m}^{-3}$ at the surface. Median values (not shown), are about half the mean values, indicating the data are skewed 

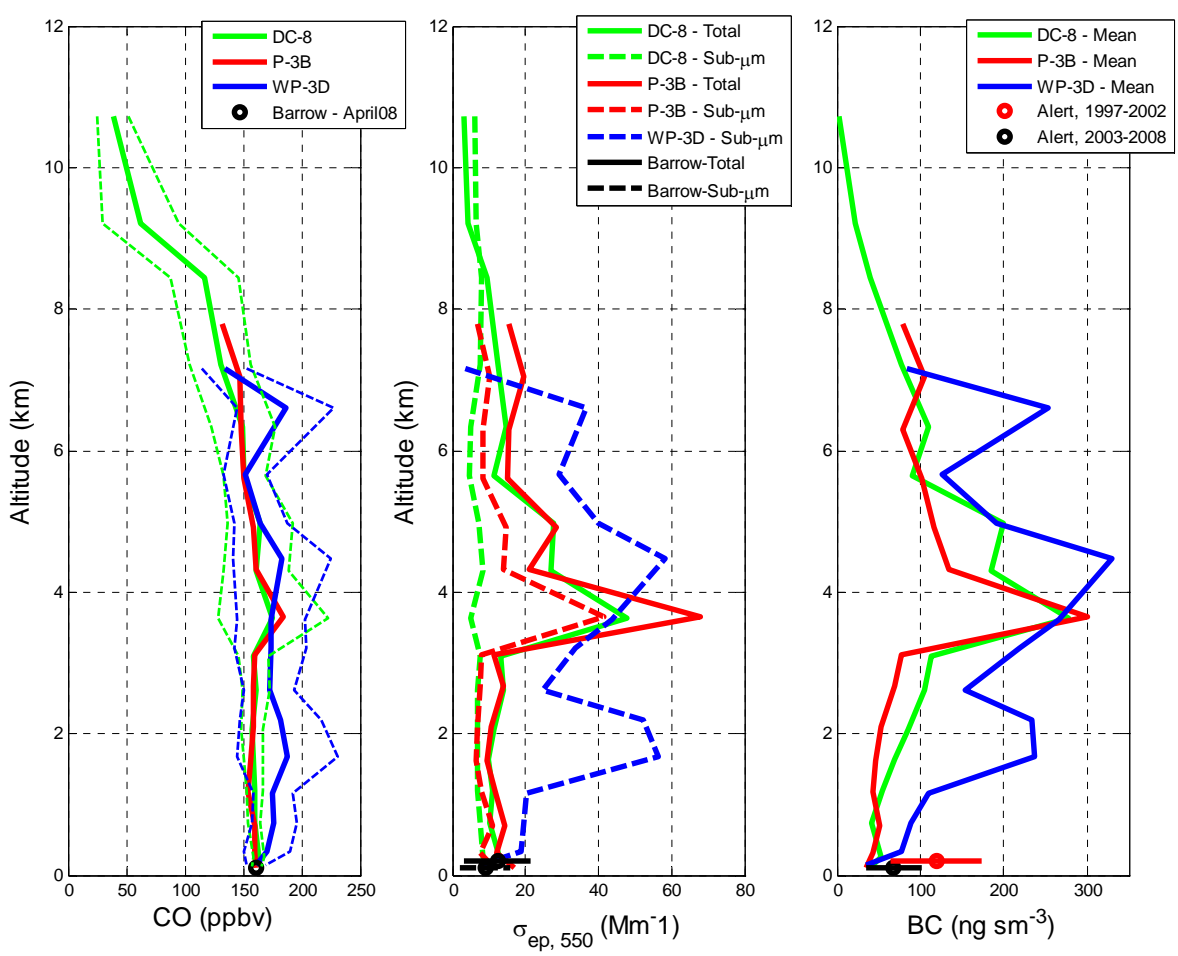

Fig. 2. Campaign mean vertical profiles of (left) carbon monoxide (+/-1 $\sigma$ dashed), (middle) total and submicrometer (solid \& dashed) dry aerosol extinction, and (right) mean black carbon as measured aboard the NASA DC-8 (green), P-3B (red) and NOAA WP-3D (blue) during ARCTAS/ARCPAC in April of 2008.

by a smaller number of relatively intense plumes. For example, black carbon concentrations in the middle troposphere range from as low as $1-5 \mathrm{ng} \mathrm{s}^{-3}$ to as much as 1500 $1800 \mathrm{ng} \mathrm{s} \mathrm{m}^{-3}$ resulting in coefficients of variation that are $>100 \%$. The aircraft near surface $(<2 \mathrm{~km})$ concentrations of BC are lower but of the same magnitude as surface based measurements at Alert, Canada from 1997-2008. Thus while surface based observations provide time series needed to document trends in emissions and their transport to the Arctic, these measurements cannot, in general, be extrapolated to derive column burdens of $\mathrm{BC}$.

Acetonitrile (ACN) (de Gouw et al., 2004; Warneke et al., 2006) and hydrogen cyanide (HCN) (Crounse et al., 2009) are commonly used to separate biomass burning (BB) influenced airmasses from airmasses dominated by urban/industrial emissions. The upper row of Fig. 3 plots black carbon mass versus $\mathrm{CO}$ mixing ratios colour coded by acetonitrile (ppbv). A priori we expect the relationship between $\mathrm{BC}$ and $\mathrm{CO}$ to vary as a function of their source (e.g. urban/industrial emissions versus biomass burning) and the airmasses transport history, i.e. dry versus wet convection followed by advection and dispersion. Relatively efficient combustion from urban/industrial sources are expected to have $\mathrm{BC}$ : $\mathrm{CO}$ slopes higher than those for relatively inefficient biomass burning sources. Similarly, while CO is approximately conserved during long-range transport, wet and dry deposition of aerosol during transport will result in lower $\mathrm{BC}: \mathrm{CO}$ ratios for all plume types. As expected, the data from each aircraft indicate several distinct relations between BC and $\mathrm{CO}$. While the DC-8 data have several small groups of data with high $\mathrm{ACN}$, the presence of high $\mathrm{ACN}$ from $\mathrm{BB}$ plumes is more frequent in the WP-3D data.

The ratio of AMS accumulation mode measurements of organic aerosol to sulfate aerosol are also useful for determining whether an airmass is strongly influenced by biomass burning (Middlebrook et al., 2008). The bottom row of Fig. 3 replots $\mathrm{BC}$ versus $\mathrm{CO}$ with datapoints now colour coded by the base-10 logarithm of the ratio of AMS Organics:Sulfate. The use of the base-10 logarithm of the ratio is used in order to better illustrate the wide range of variability in the Organics:Sulfate ratio between 1:10 to as much as 20:1. The AMS data confirm that most airmasses sampled by the DC- 8 and the P3-B are relatively low in organics while there are numerous airmasses from the WP-3D data with organics concentrations 3-20 times their sulfate content $\left(\log _{10}=0.5-1.3\right.$ in the plot). More detail regarding these biomass burning aerosol can be found in ARCPAC related publications including (Spackman et al., 2010; Warneke et al., 2009, 2010).

In an effort to separate Western Arctic airmasses dominated by biomass burning emissions from those dominated by urban/industrial pollution we select a threshold value of 160 pptv of acetonitrile and an AMS Organics:Sulfate ratio 

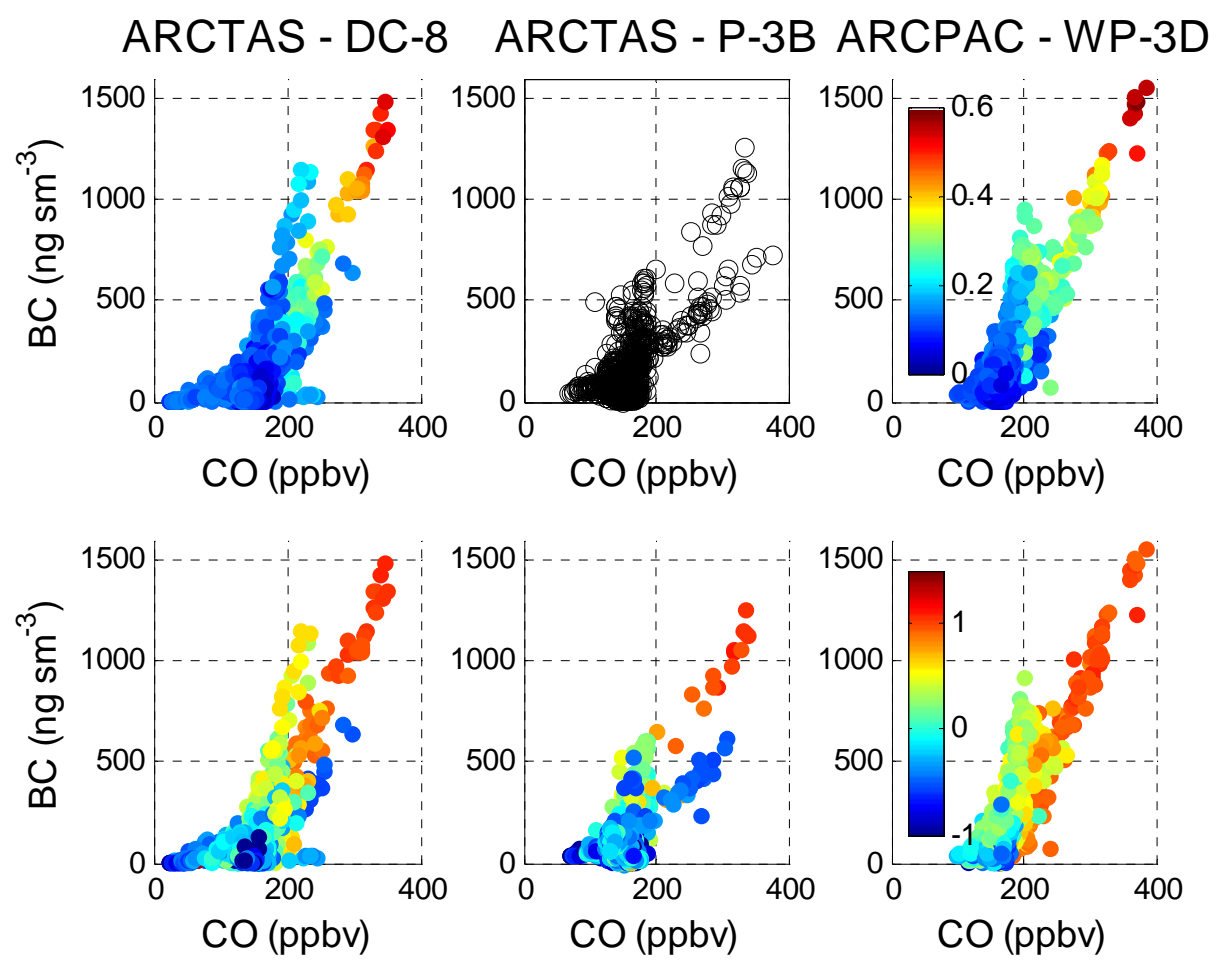

Fig. 3. (top-row) 1-min averaged black carbon concentration (@ STP) plotted versus CO concentration (ppbv) and coloured by the concentration of acetonitrile, $\mathrm{CH}_{3} \mathrm{CN}$ (ppbv). (bottom-row) same as above but coloured by base-10 logarithm of the ratio of AMS Organics:Sulfate.

of $>2: 1\left(\log _{10}\left(\mathrm{Org}: \mathrm{SO}_{4}\right)>0.30\right)$ as two independent methods of stratifying the $\mathrm{CO}$ and black carbon data. We recognize that these values were chosen arbitrarily and that mixing and other processes will confound a true separation of airmass types. For example, the acetonitrile threshold is an absolute concentration and will subsequently be affected by airmass dilution, while the AMS-derived criteria is relative (a ratio), and will not change until plume concentrations approach the AMS instrument's limits-of-detection. However, the objective here is to compare/contrast the observations from each platform in an effort to describe, in general, the presence of absorbing aerosol in the Western Arctic and to what extent is may be derived from urban/industrial versus biomass burning sources.

Figure 4 plots histograms for all $\mathrm{CO}$ data acquired north of $55^{\circ} \mathrm{N}$ for each platform. A subset of the histogram corresponding to the BB dominated plumes is over-plotted in red. The upper row of Fig. 4 uses Method-1, stratification using ACN, while the lower row uses Method-2, stratification based upon AMS ratios of Organics:Sulfate. Table 1 summarizes, as a percentage, the number of 60 -s average data points classified as "biomass burning dominated" from the available $\mathrm{CO}$ data $(\mathrm{N}$, at $60-\mathrm{s})$. The location and number of 60-s averaged data points recorded by the SP2 differs slightly from those recorded by the $\mathrm{CO}$ instruments. Figure 5 plots histograms of the base-10 logarithm of black carbon concentrations $\left(\mu \mathrm{g} \mathrm{s} \mathrm{m}^{-3}\right)$ measured by the SP2 instruments, includ- ing the subsets of the data classified as BB according to each method of stratification. Table 2 summarizes as a percentage the black carbon data classified as BB from the available SP2 data for each aircraft.

Despite sampling over Alaska during a similar time period, the frequency with which each aircraft sampled biomass burning influenced airmasses is very different. This difference holds regardless of whether we base the assessment on the available $\mathrm{CO}$ or $\mathrm{BC}$ data or whether we stratify biomass burning dominated cases using acetonitrile or the ratio of AMS Organics:Sulfate. As evident in Tables 1 and 2, by using acetonitrile or AMS chemistry to stratify the data, we conclude that $11-14 \%$ of the samples were dominated by $\mathrm{BB}$ emissions. Of greater interest is the implied proportion of $\mathrm{BC}$ over the Western Arctic which can be attributed to BB emissions versus BC produced from urban/industrial activities. These statistics are summarized in Table 3 where the observations from all three airborne platforms are combined. The BB-influenced airmasses, as defined here, account for $\sim 42-47 \%$ of the total BC burden.

In-situ observations provide relatively accurate and precise measurements of absorbing aerosol along the aircraft flightpaths. However the limited duration ( 1-month) of the intensive observation period, as well as spatial and temporal variability of aerosol plumes means that aircraft data alone cannot be used to determine the representativeness of the sampling strategy, nor the seasonal or interannual variability 

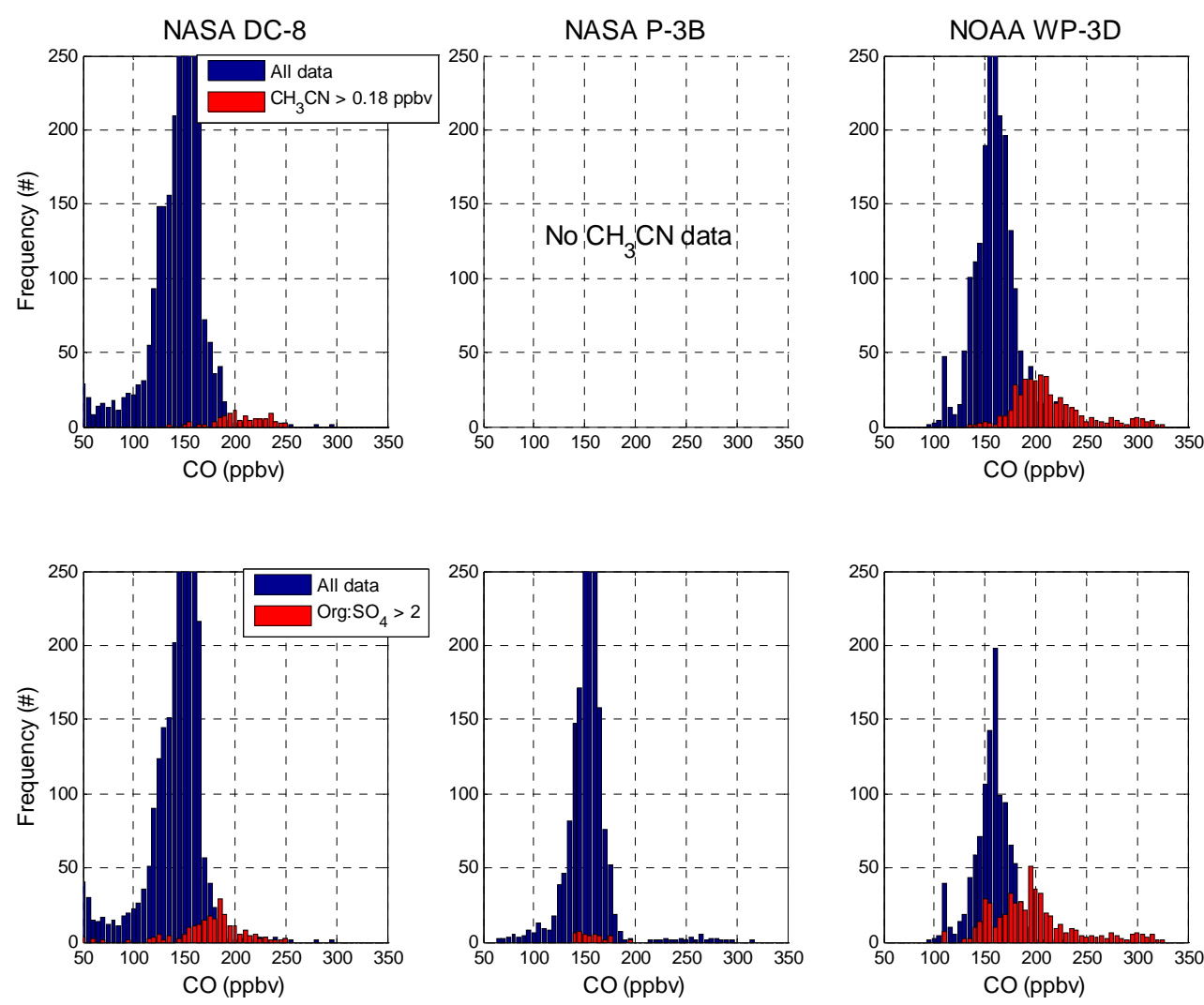

Fig. 4. Histograms of $\mathrm{CO}$ over the Western Arctic during April 2008. Top: $\mathrm{CO}$ data stratified using a threshold concentration of $\mathrm{CH}_{3} \mathrm{CN}$ of 0.160 ppbv to identify BB airmasses. Bottom: CO data stratified using a threshold ratio of AMS Organics:Sulfate of 2.0 to identify BB airmasses.

Table 1. Percentages of airmasses classified as biomass burning for each aircraft. Two methods of stratification are employed in order to characterize all of the available date for carbon monoxide (CO). There are no measurements of acetonitrile aboard the NASA P-3B.

\begin{tabular}{lcccc}
\hline Platform & \multicolumn{2}{c}{ Method-1 } & ACN $>0.160$ ppbv & \multicolumn{2}{c}{ Method-2 Org:SO4 $>2.0$} \\
\hline & $\%$ & $\mathrm{~N}(60-\mathrm{s})$ & $\%$ & $\mathrm{~N}(60-\mathrm{s})$ \\
DC-8 & $5.5 \%$ & 3352 & $7.7 \%$ & 3461 \\
P-3B & & & $2.6 \%$ & 2220 \\
WP-3D & $17 \%$ & 2905 & $32 \%$ & 1592 \\
\hline Total & $11 \%$ & 6257 & $11 \%$ & 7273 \\
\hline
\end{tabular}

of absorbing aerosol over the Western Arctic. This consideration is particularly important as the ARCTAS/ARCPAC results demonstrate that Spring 2008 was a relatively intense year for BB emissions from Asia (Fisher et al., 2010; Warneke et al., 2009), with potentially reduced efficiency in the transport of urban/industrial emissions to the region (Fuelberg et al., 2010).

Investigations into the spatial and temporal variability of $\mathrm{BC}$ over the Arctic domain are best suited to regional and global chemistry/aerosol models constrained by both
Table 2. Percentages of airmasses classified as biomass burning for each aircraft. Two methods of stratification are employed in order to characterize all of the available date for black carbon mass (BC). There are no measurements of acetonitrile aboard the NASA P-3B.

\begin{tabular}{lcccc}
\hline Platform & \multicolumn{2}{c}{ Method-1 } & ACN $>0.160$ ppbv & \multicolumn{2}{c}{ Method-2 } & Org: $\mathrm{SO}_{4}>2.0$ \\
\hline & $\%$ & $\mathrm{~N}(60-\mathrm{s})$ & $\%$ & $\mathrm{~N}(60-\mathrm{s})$ \\
DC-8 & $7.6 \%$ & 2342 & $10 \%$ & 2489 \\
P-3B & & & $2.8 \%$ & 2087 \\
WP-3D & $21 \%$ & 2249 & $38 \%$ & 1275 \\
\hline Total & $14 \%$ & 4591 & $14 \%$ & 5851 \\
\hline
\end{tabular}

in-situ measurements and satellite retrievals (e.g. Fisher et al., 2010). Climate models which include aerosols and that demonstrate reasonable fidelity with respect to in-situ measurements obtained during the IPY could be used to assess the representativeness of the ARCTAS/ARCPAC aircraft sampling, potentially improving future collaborations. However recent comparisons between global models and insitu airborne measurements of $\mathrm{BC}$ highlight the huge diversity among model simulations, particularly over the Arctic domain (Koch et al., 2009). 

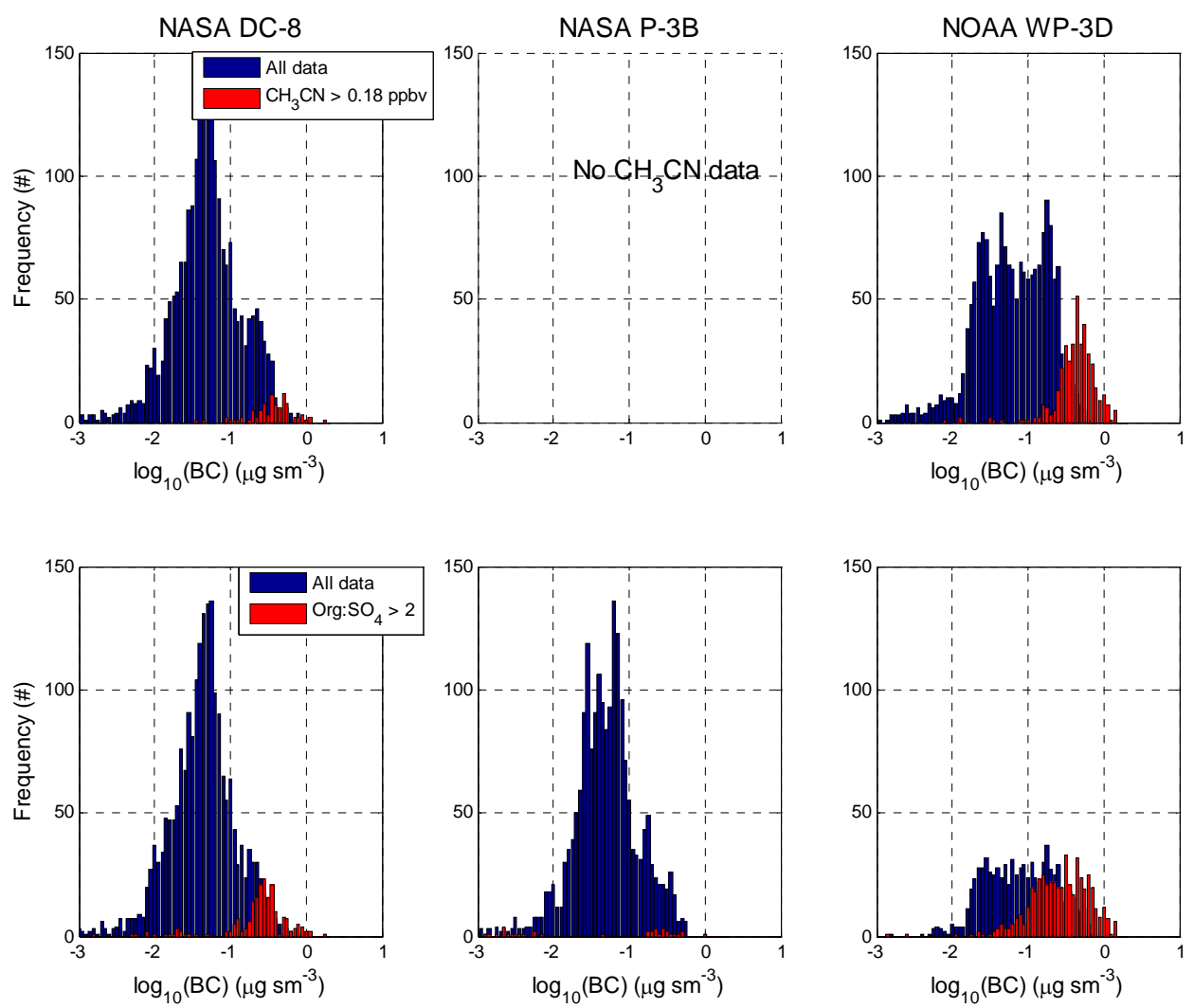

Fig. 5. Histograms of base-10 logarithm of BC concentrations over the Western Arctic during April 2008. (top-row) BC data stratified using a threshold concentration of $\mathrm{CH}_{3} \mathrm{CN}$ of 0.160 ppbv to identify $\mathrm{BB}$ airmasses. (bottom row) $\mathrm{BC}$ data stratified using a threshold ratio of AMS Organics: $\mathrm{SO}_{4}^{2-}$ of 2.0 to identify BB airmasses.

Table 3. Burden, expressed as a percentage of total burden, of black carbon mass associated with biomass burning plumes compared to the mass of black carbon for all airmasses sampled during ARCTAS/ARCPAC.

\begin{tabular}{lcc}
\hline Platform & Method-1 ACN $>0.160 \mathrm{ppbv}$ & Method-2 Org:SO $4>2.0$ \\
\hline DC-8 & $33 \%$ & $41 \%$ \\
P-3B & $56 \%$ & $12 \%$ \\
WP-3D & $47 \%$ & $64 \%$ \\
\hline Total & & $42 \%$ \\
\hline
\end{tabular}

Inter-model diversity when simulating the atmospheric burden (load) of aerosol species at the poles is slightly lower for BC than for organic aerosol and dust (Textor et al., 2006). However, simulating organic aerosol is particularly complex (Kanakidou et al., 2005), with high diversity among models predicting their optical properties globally (Kinne et al., 2006). Given the important role of the crysophere in global climate and sea level, the in-situ airborne measurements collected by NASA and NOAA during ARCTAS and ARCPAC provide valuable constraints for future simulations of absorbing aerosol in the atmospheric of the Western Arctic. How- ever, due to its remote location, harsh environment, and atmospheric conditions that preclude comprehensive satellite coverage, the atmosphere of the Western Arctic likely remains critically undersampled.

\section{Discussion}

\subsection{Mass absorption efficiency of light absorbing carbon}

Global climate models need to accurately simulate sources, sinks and the vertical distribution of absorbing aerosols in order to evaluate their radiative effects. Models also need to ensure that intensive aerosol parameters, e.g. single scattering albedo, are accurately simulated or parameterized (Anderson et al., 1999; Haywood and Shine, 1995). A key parameter linking BC emissions to their light absorbing properties is the mass absorption efficiency, with units of $\mathrm{m}^{2} \mathrm{~g}^{-1}$ (MAE). To first order this quantity can be obtained from regressions of light absorption at a given wavelength against light absorbing mass. However, there are several factors which complicate this conceptually simple analysis for black carbon. First, although black carbon (BC) typically 

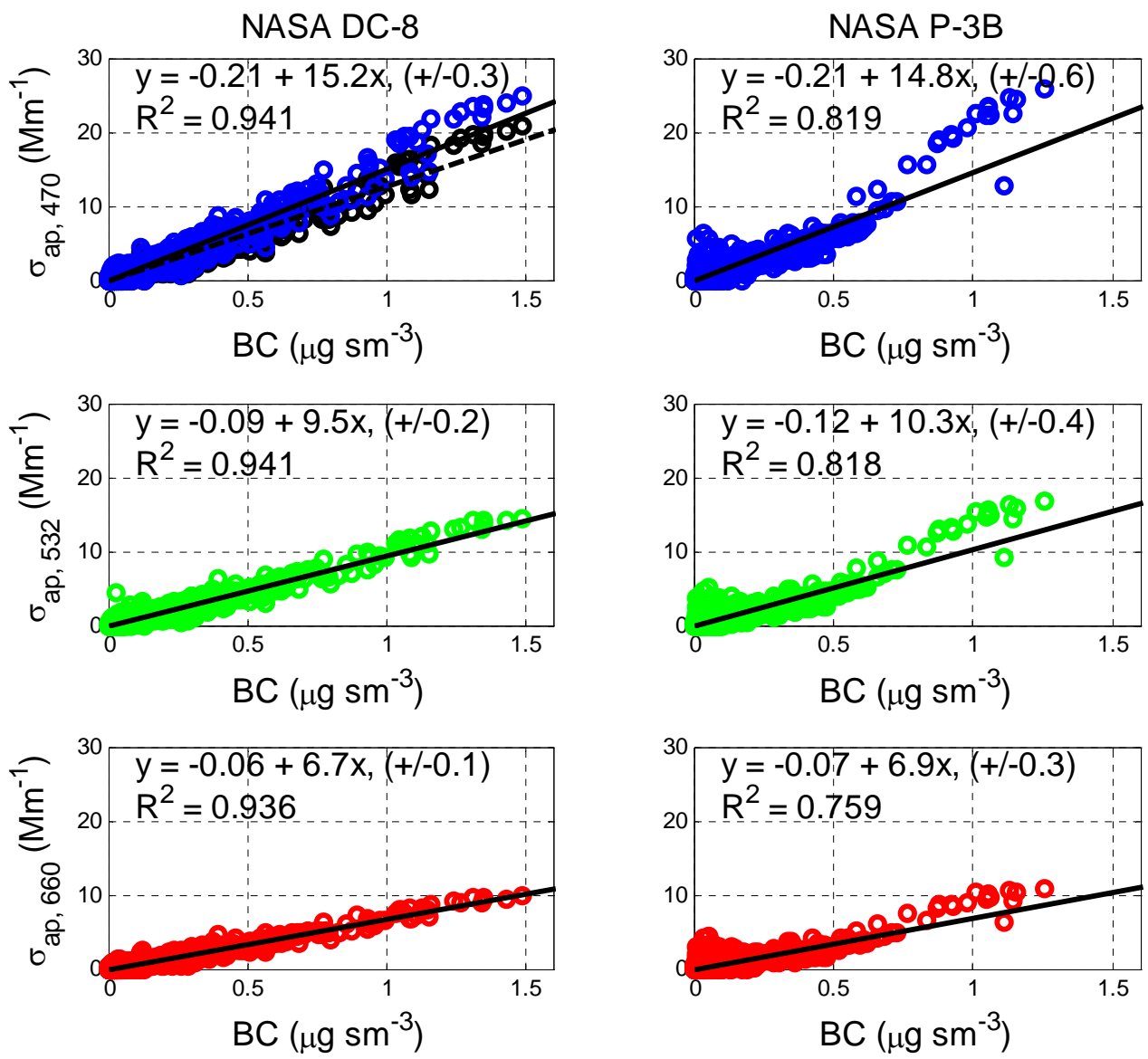

Fig. 6. Apparent mass absorption efficiency of $\mathrm{BC}$ in Arctic aerosol using total aerosol absorption at each of the 3 PSAP wavelengths; DC-8 data on the left, P-3B data on the right. DC- 8 data at $470 \mathrm{~nm}$ wavelength (black symbols, dashed line) have been corrected (blue symbols, solid line) based on wingtip-to-wing-tip intercomparisons with the P-3B.

dominates aerosol absorption, absorption by organic carbon, e.g. humic-like substances (Graber and Rudich, 2006), and mineral dust (Lafon et al., 2006; Sokolik and Toon, 1996) can also contribute to total aerosol absorption. Second, absorption by internally mixed BC is enhanced by absorbing and non-absorbing coatings (Bond et al., 2006; Fuller et al., 1999; Lack and Cappa, 2010; Schnaiter et al., 2006). These coatings are common in both pollution (de Gouw and Jimenez, 2009; DeCarlo et al., 2010) and biomass burning plumes (Clarke et al., 2007; Gyawali et al., 2009). Finally, the accuracy of filter-based light absorption measurements (Cappa et al., 2008; Lack et al., 2008; Subramanian et al., 2007), the definitions of elemental versus black carbon, and the inter-comparability of their independent measurement are subjects of ongoing study (Schauer et al., 2003).

Despite these complications, regressions of total light absorption versus accumulation mode black carbon for each of 3-wavelengths $(\lambda 470,530,660 \mathrm{~nm})$ are relatively consistent between the NASA DC- 8 and P-3B during ARCTAS (Fig. 6). MAE 470 shows the greatest disparity with a P-3B value of $14.8 \mathrm{~m}^{2} \mathrm{~g}^{-1}$, some $17 \%$ higher than the $12.7 \mathrm{~m}^{2} \mathrm{~g}^{-1}$ estimated from the DC-8 data set (black dashed line). DC8 and P-3B MAE's at 530 are in good agreement with values of $9.5 \pm 0.2$ and $10.3 \pm 0.4 \mathrm{~m}^{2} \mathrm{~g}^{-1}$ respectively; values at $660 \mathrm{~nm}$ are also in good agreement at $6.7 \pm 0.1$ and $6.9 \pm 0.3$. While instrument uncertainty could potentially account for differences in blue absorption of $10-15 \%$, these effects are typically manifest at low concentrations due to instrument noise. The cause for the discrepancy is an erroneously low blue absorption value for the DC-8 PSAP instrument - a discrepancy identified during wingtip-to-wingtip intercomparisons among the aircraft. After empirically correcting the DC-8 blue absorption data (using NASA P-3B data) the slope and uncertainty of the $\mathrm{MAE}_{470}$ regression are recalculated at $15.2 \pm 0.3 \mathrm{~m}^{2} \mathrm{~g}^{-1}$. The corrected data are used throughout the remainder of this manuscript.

As noted above, these MAE estimates represent total absorption efficiency and include absorption by non-BC carbonaceous species, mineral dust, and possible amplification due to coatings. In an effort to better constrain and separate the MAE's for BC and brown carbon $(\mathrm{BrC})$, we take a closer look at the NASA P-3B data. First, the 1-min averages are 

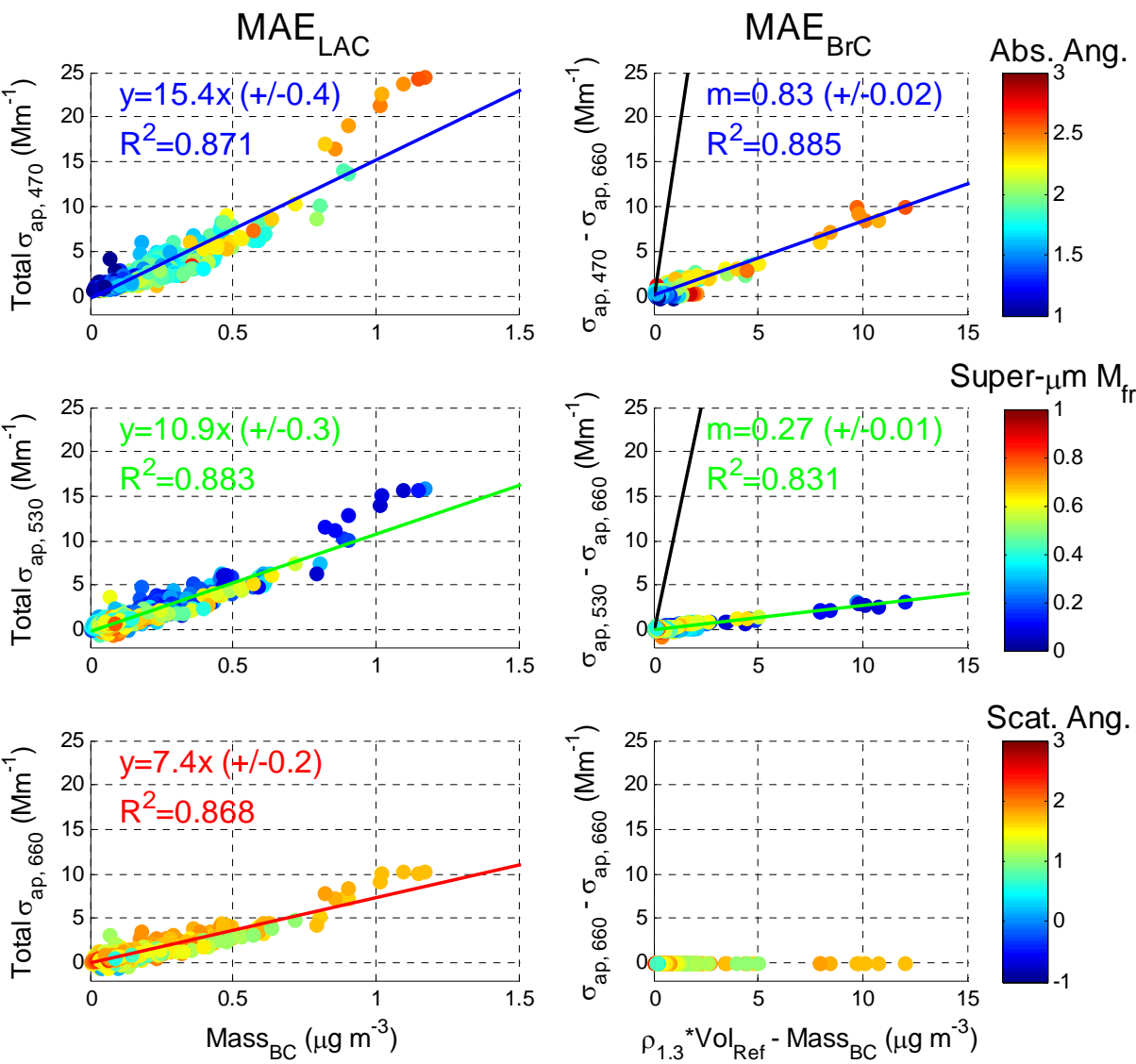

Fig. 7. Total mass absorption efficiency at 3-wavelengths for light absorbing carbon (left) and for brown carbon (right), normalized to absorption at $660 \mathrm{~nm}$. Rows are color-coded by absorption Ångström exponent (top), coarse mode fraction (middle), and scattering Ångström exponent (bottom).

pooled into 2-min averages and a lower threshold of $3 \mathrm{Mm}^{-1}$ for total scattering $(550 \mathrm{~nm})$ is used to exclude low signal-tonoise absorption data (typically PSAP noise is $\sim 0.5 \mathrm{Mm}^{-1}$ for a $300 \mathrm{~s}$ sample). Next the ratio of submicrometer to total scattering is used to reduce the influence of high dust cases, i.e. we discard samples with a fine-mode fraction of scattering $\left(\mathrm{FMF}_{\text {scat }}\right)$ below 0.6 (Anderson et al., 2003; McNaughton et al., 2009). After applying this stratification the sample number is reduced by about half to $N=\sim 700$.

The first column of Fig. 7 replots the P-3B total MAE for light absorbing carbon (LAC) using these criteria. The top row of data are color-coded by absorption Ångström exponent (steep dependence $=$ red; shallow dependence $=$ blue), the center row is colored by supermicrometer mass fraction (coarse-mode dominated $=$ red; fine-mode dominated =blue), and the final row is colored by scattering Ångström exponent (coarse-mode dominated = red; finemode dominated $=$ blue). After performing this stratification we find that the MAE's for total aerosol change very little compared to the bulk analysis in Fig. 6 and therefore conclude that total absorption is dominated by light absorbing carbon.
The wavelength dependence of black carbon is relatively weak and expected to vary as $\lambda^{-1}$ (Kirchstetter et al., 2004). Absorption by brown carbon is typically very small at $660 \mathrm{~nm}$ where we argue (Clarke et al., 2007) that it is primarily due to black carbon. Making use of this assumption and the PSAP measurements of absorption at $660 \mathrm{~nm}$, it is possible to compute excess light absorption at 470 and $530 \mathrm{~nm}$, i.e. absorption which is potentially due to brown carbon and having a wavelength dependence in excess of $\lambda^{-1}$. We can also use the HiGEAR thermal volatility measurements of the aerosol size distribution to determine submicrometer refractory volume $\left(420^{\circ} \mathrm{C}, \tau \sim=0.1 \mathrm{~s}\right)$ (Clarke et al., 2007, 2004; McNaughton et al., 2009). The refractory volume is then converted to an estimate of non-BC refractory mass $\left(M_{\text {ref }}\right)$ by assuming it has a density of $1.3 \mathrm{~g} \mathrm{~cm}^{-1}$ and then subtracting the mass of BC measured concurrently by the SP2.

The second panel of Fig. 7 plots excess absorption versus $M_{\text {ref }}$ and the regressions based upon them. Using this technique we compute an MAE for the refractory mass of $0.83 \pm 0.02$ and $0.27 \pm 0.01 \mathrm{~m}^{2} \mathrm{~g}^{-1}$ for $470 \mathrm{~nm}$ and $530 \mathrm{~nm}$ respectively. Here \pm values represent uncertainties to the regression. When instrument noise, flow rate uncertainties 
etc. are added in quadrature, the uncertainty estimates are $0.83 \pm 0.15$ and $0.27 \pm 0.08 \mathrm{~m}^{2} \mathrm{~g}^{-1}$ for $470 \mathrm{~nm}$ and $530 \mathrm{~nm}$ wavelengths. As the computations are normalized to the absorption measurement at the $660 \mathrm{~nm}$ wavelength, we cannot compute an MAE value at $660 \mathrm{~nm}$.

The actual constituents of $M_{\text {ref }}$ will include both refractory organic matter as well as non-organic submicrometer refractory aerosol from urban/industrial and natural sources. These constituents may or may not be responsible for enhanced absorption at short wavelengths. However, the data were pre-screened to reduce the influence of absorbing dust by only using data for which $\mathrm{FMF}_{\text {scat }}>0.6$. We also recognize that some light-absorbing organic species may volatilize below our size distribution pre-heater temperature of $420^{\circ} \mathrm{C}$ (Andreae and Gelencser, 2006). However, in the absence of more detailed chemical information, we are explicitly assuming that $M_{\text {ref }} \simeq$ brown carbon $(\mathrm{BrC})$.

To evaluate the validity of this assumption, the MAE values calculated using the ARCTAS data can be compared to MAE values for brown carbon from INTEX-A (Clarke et al., 2007) as well as those computed by Yang et al. (2009) during EAST-AIRE ( $\mathrm{Li}$ et al., 2007). Note that the Yang et al. absorbing mass values are based on EC/OC measurements using the Sunset Labs technique (Huebert et al., 2004a; Kline et al., 2004), while their absorption measurements at 470 , 520 and $660 \mathrm{~nm}$ use a corrected 7-wavelength aethalometer (Arnott et al., 2005; Bond et al., 1999). The Yang et al., aethalometer data were compared to a corrected (Virkkula et al., 2005) 3- $\lambda$ PSAP and showed excellent agreement (Yang, 2007). However, the updated PSAP correction (Virkkula, 2010) means that we can expect both the INTEX-A and the EAST-AIRE estimates of MAE's to be low by $\sim 10-30 \%$. Also note that the Yang et al. MAE $\mathrm{BrC}_{\mathrm{BrC}}$ values at all wavelengths (e.g. $0.32 \mathrm{~m}^{2} \mathrm{~g}^{-1} @ 660 \mathrm{~nm}$ ) are normalized to BC absorption at $990 \mathrm{~nm}$ rather than $660 \mathrm{~nm}$. Thus to fairly compare these values we need to adjust the ARCTAS brown carbon MAE values by adding $0.32 \mathrm{~m}^{2} \mathrm{~g}^{-1}$ to the ARCTAS MAE values at 470 and $530 \mathrm{~nm}$ 's. Estimates of absorption by this refractory organic matter, i.e. $\mathrm{BrC}$, are summarized in Table 4 and show good agreement between independent measurements using different techniques, at different locations, and during different seasons.

By measuring the refractory mass and establishing an MAE for brown carbon, we can estimate the absorption by brown carbon for each sample. We then subtract this value from total aerosol absorption in order to derive a better estimate for the BC-only absorption. Figure 8 summarizes this analysis by regressing total absorption, minus absorption from brown carbon, against SP2 measurements of BC. Once again the upper, middle and lower panels are colour coded according to absorption Ångström exponent (top), coarse mode scattering fraction (middle) and scattering Ångström exponent (bottom). Regressions remain robust, even improving slightly.
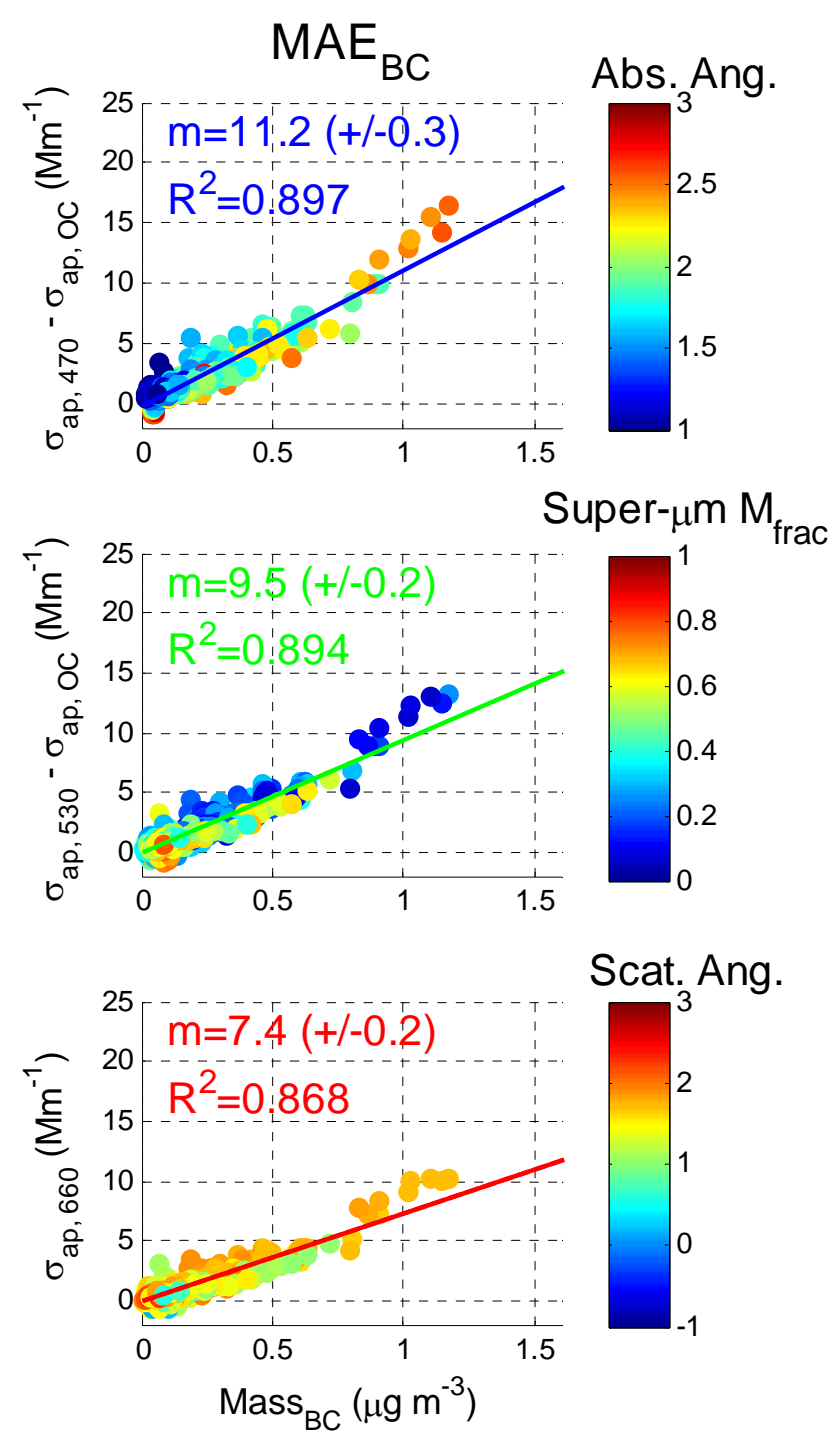

Fig. 8. Regressions of BC mass absorption efficiency at 3wavelengths normalized to absorption at $660 \mathrm{~nm}$. Rows are colorcoded by absorption Ångström exponent (top), coarse mode fraction (middle), and scattering Ångström exponent (bottom).

The success of this method for refining the estimated $\mathrm{MAE}_{\mathrm{BC}}$ is evident for the cluster of highest absorption Ångström exponent $(\sim 2.5)$ data in the upper left panel of Fig. 7. Absorption of blue light $(470 \mathrm{~nm})$ by this cluster of data differs significantly from the initial regression. By subtracting the apparent absorption by brown carbon (product of brown carbon MAE and mass of $M_{\text {ref }}$ ) this cluster of data moves closer to the regression and improves the $R^{2}$ by $\sim 3 \%$. Taking the Ångström exponent of the regression slopes we can verify that the regression is approximately preserving a $1 / \lambda$ dependence (i.e. $-\log (11.2 / 7.4) / \log (470 / 660=1.2)$. PSAP and SP2 flow uncertainties $(<5 \%)$ and uncertainties of the regression (+/-0.2 to $\left.0.3 \mathrm{~m}^{2} \mathrm{~g}^{-1}\right)$ are smaller 
Table 4. Summary of mass absorption efficiencies for refractory organic material assumed to be BrC normalized to absorption at $660 \mathrm{~nm}$ and to absorption at $990 \mathrm{~nm}$.

\begin{tabular}{lllll}
\hline Wavelength $(\mathrm{nm})$ & $\begin{array}{l}\text { ARCTAS MAE } \\
\text { Norm. to 660 nm }\end{array}$ & $\begin{array}{l}\text { INTEX-A MAE } \\
\text { Norm. to 660 nm }\end{array}$ & $\begin{array}{l}\text { ARCTAS MAE } \\
\text { Norm. to 990 nm }\end{array}$ & $\begin{array}{l}\text { EAST-AIRE MAE } \\
\text { Norm. to 990 nm }\end{array}$ \\
\hline 470 & $0.83 \pm 0.15$ & $0.63 \pm 0.02$ & $1.15 \pm 0.15$ & 1.01 \\
530 & $0.27 \pm 0.08$ & $0.09 \pm 0.01$ & $0.59 \pm 0.08$ & 0.63 \\
660 & N/A & N/A & $0.32^{*}$ & 0.32 \\
\hline
\end{tabular}

* By definition the ARCTAS $660 \mathrm{~nm}$ MAE is equal to the EAST-AIRE value of $0.32 \mathrm{~m}^{2} \mathrm{~g}^{-1}$ when the data are normalized to BC absorption at $990 \mathrm{~nm}$ wavelengths.

than differences in absorption measured during wingtip-towingtip aircraft intercomparisons $(-8 \%$ to $+13 \%)$. We also performed a sensitivity analysis given an uncertainty for the wavelength dependence of absorption by black carbon of $1 / \lambda^{(0.9-1.6)}$. If we assume that these uncertainties add in quadrature, then our best estimates for ARCTAS MAE $\mathrm{BC}_{\mathrm{BC}}$ for each wavelength are $11.2 \pm 0.8,9.5 \pm 0.6$ and $7.4 \pm 0.7 \mathrm{~m}^{2} \mathrm{~g}^{-1}$. We can now compare the ARCTAS MAE values for BC to those already reported in peer-reviewed literature.

Values for $\mathrm{MAE}_{530}$ for $\mathrm{BC}$ during INDOEX ranged between $6.6-8.1 \mathrm{~m}^{2} \mathrm{~g}^{-1}$ (Mayol-Bracero et al., 2002). Two studies using ACE-Asia data reported $11 \pm 5 \mathrm{~m}^{2} \mathrm{~g}^{-1}$ (Mader et al., 2002) and $7 \pm 2 \mathrm{~m}^{2} \mathrm{~g}^{-1}$ (Clarke et al., 2004). Recent measurements in the East Asian source regions report $10.5 \pm 0.7 \mathrm{~m}^{2} \mathrm{~g}^{-1}$ at $530 \mathrm{~nm}$ (Kondo et al., 2009) and $11.1,10.0$ and $7.9 \mathrm{~m}^{2} \mathrm{~g}^{-1}$ at 470,530 and $660 \mathrm{~nm}$ (Yang et al., 2009). Kondo et al. (2009), note that their values are $\sim 1.8$ times higher than those calculated from theory, $5.7 \pm 0.3 \mathrm{~m}^{2} \mathrm{~g}^{-1}$ at $530 \mathrm{~nm}$. They investigated this behavior and attributed it to filter-matrix effects.

Our calculations for the MAE of BC account for filter matrix effects (Virkkula, 2010; Virkkula et al., 2005), but do not account for absorption enhancements due to coatings. Thus results report here should be viewed as the mass absorption efficiency of dry $(\mathrm{RH}<40 \%)$ aerosol found in the atmospheric environment rather than an MAE for uncoated graphitic carbon or values for pure black carbon particulate calculated from theory. Coating of $\mathrm{BC}$ particulate is expected to result in $\sim 35 \%$ absorption enhancement depending on the ratio of shell to core diameters (Fuller et al., 1999), or as much as a factor of 1.8-2.0 depending on the wavelength of interest and nature of the coatings (Lack and Cappa, 2010; Schnaiter et al., 2005).

If we assume that coating by non- or weakly-absorbing aerosol results in a $\sim 35 \%$ enhancement then our reduced MAE value of $7.0+/ 0.6 \mathrm{~m}^{2} \mathrm{~g}^{-1}$ at $530 \mathrm{~nm}$ is in good agreement with the value of $7.5 \pm 0.3 \mathrm{~m}^{2} \mathrm{~g}^{-1}$ (@550 nm) reported for $\mathrm{BC}$ in the review by Bond et al. (2006) and $7.1 \mathrm{~m}^{2} \mathrm{~g}^{-1}$ recently reported for diesel soot (Adler et al., 2010). If absorption by uncoated BC is being over estimated by $80 \%$ then a reduced value of $\sim 5.3 \mathrm{~m}^{2} \mathrm{~g}^{-1}$ is comparable to Fuller et al. (1999) who reported an MAE value of $5.4 \mathrm{~m}^{2} \mathrm{~g}^{-1}$ for amorphous graphitic spheres from diesel soot. The ARCTAS/ARCPAC value of $\sim 5.3 \mathrm{~m}^{2} \mathrm{~g}^{-1}$ is also effectively identical to Kondo et al. (2009) who reported $5.7 \pm 0.3 \mathrm{~m}^{2} \mathrm{~g}^{-1}$ and recently measured values of $5.5 \mathrm{~m}^{2} \mathrm{~g}^{-1}$ (Kondo et al., 2011). A more detailed analysis of potential absorption enhancements using the aerosol size distributions and SP2 measurements of the $\mathrm{BC}$ size distributions during the ARCTAS/ARCPAC field campaigns is warranted, and should form the basis of future analyses.

\subsection{Mineral Dust over the Western Arctic}

A salient observation from the ARCTAS/ARCPAC field campaigns is the ubiquity of supermicrometer aerosol in the free troposphere (FT) of the Western Arctic. The first panel of Fig. 9 plots vertical profiles of NASA P-3B (red) and the NOAA WP3D (blue) supermicrometer volume $\left(V_{\text {coa }}\right)$. Mean and median volume concentrations are likely higher aboard the NOAA WP-3D because of the use of an active low-turbulence inlet (Huebert et al., 2004b; Wilson et al., 2004 ) with a $50 \%$ passing efficiency larger than the passive solid diffuser inlets used aboard the NASA DC-8 and P-3B (McNaughton et al., 2007). Intense plumes of coarse mode aerosol were rare during ARCTAS, however the WP-3D did encounter one such plume with 60 -s average volume greater than $50 \mu \mathrm{m}^{3} \mathrm{~m}^{-3}$. The effect of this plume on the mean value of $V_{\text {coa }}$ for the WP-3D is shown in Fig. 9 compared to the mean $\mathrm{P}-3 \mathrm{~B}$ data.

The second panel of Fig. 9 summarizes the mean fine mode fraction (FMF) of extinction and aerosol volume North of $55^{\circ} \mathrm{N}$ during ARCTAS/ARCPAC. Measurements of total and submicrometer extinction are common to the NASA aircraft only, and are plotted as solid green (DC-8) and blue (P-3B) lines; supermicrometer volume is common between the two P-3's and plotted as dashed lines. The DC-8 spent the most time at high altitude and in the High Arctic (i.e. North of $70^{\circ} \mathrm{N}$ ), whereas the two P-3's spent more time in the mid- and lower-troposphere and concentrated their sampling near Alaska. The DC-8 submicrometer nephelometer also periodically malfunctioned during the campaign, resulting in fewer samples in Fig. 9 profile $(N=600)$ compared to the P-3B $(N=2000)$ and WP-3D $(N=1500)$. The optical and microphysical aerosol measurements both indicate 

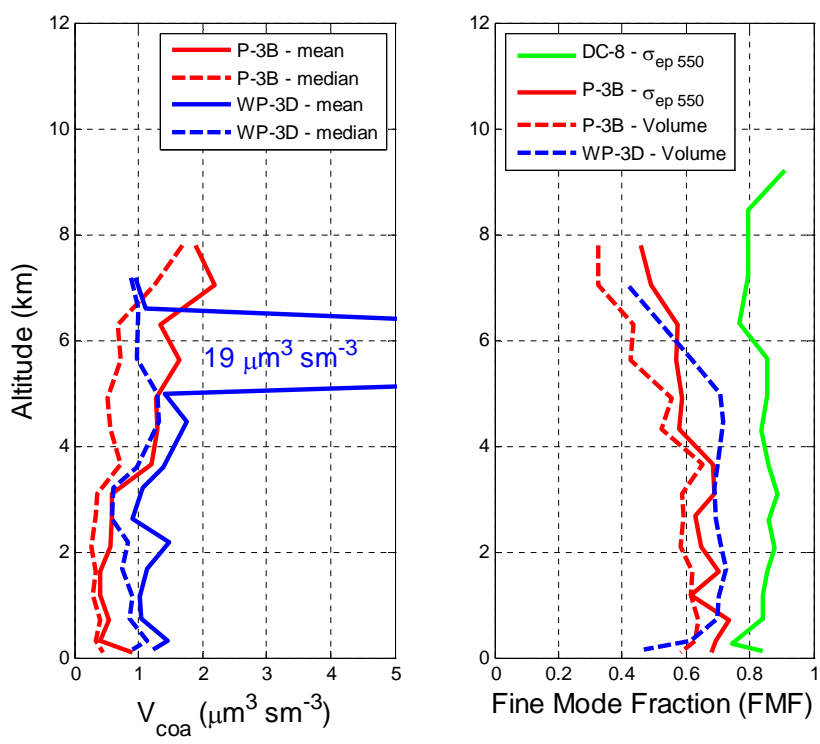

Fig. 9. (left) Profiles of mean and median supermicrometer volume $\left(V_{\text {coa }}\right)$ from the NASA P-3B and the NOAA WP-3D. (right) Profiles of fine-mode fraction of extinction (solid lines) and aerosol volume (dashed lines) - Note that $N=600$ for the DC- 8 extinction profile due to instrument malfunction. For comparison $N=2000$ for the P-3B and $N=1500$ for the WP-3D.

that supermicrometer aerosol concentrations are highest between 6 and $8 \mathrm{~km}$, decreases toward the surface but then increases again below $\sim 1 \mathrm{~km}$. The PALMS instrument aboard the WP-3D measured supermicrometer particle chemistry during ARCPAC, and provides the unique ability to separate these aerosol into dust and sea salt particle types (Froyd et al., 2009). Above $\sim 4 \mathrm{~km}$ mineral dust particles account for $>80 \%$ of the total number of particles analyzed by the PALMS. Below $4 \mathrm{~km}$ the number fraction of dust particles then decreases, such that sea salt particle types account for $60-80 \%$ of the particle number below $1 \mathrm{~km}$.

These results can be put further into context by examining the vertical profiles of fine mode fraction of scattering $\left(\mathrm{FMF}_{\text {scat }}\right.$; Anderson et al., 2003) measured during other airborne field campaigns, employing the same inlets and/or instrumentation, while sampling over the North Pacific and North America in the Spring and Summer (Clarke and Kapustin, 2010). Figure 10 plots $\mathrm{FMF}_{\text {scat }}$ profiles measured during ACE-Asia (Clarke et al., 2004; Huebert et al., 2003), INTEX-NA (Clarke et al., 2007; Shinozuka et al., 2007), INTEX-B/IMPEX (Dunlea et al., 2009; McNaughton et al., 2009), and ARCTAS. In the figure the analysis is restricted to cases where total light scattering is greater than $3 \mathrm{Mm}^{-1}$ to eliminate ratios derived from low signal-to-noise scattering values which can skew the summary statistics. We plot the fractions with respect to atmospheric pressure to better normalize measurements occuring over different terrain and during different seasons.
The ACE-Asia measurements (Spring, 2001) of the East Asian source region are dominated by "mixed airmasses" $\left(0.3<\mathrm{FMF}_{\text {scat }}<0.6\right)$ until the $700 \mathrm{mb}$ level where the average $\mathrm{FMF}_{\text {scat }}$ drops below 0.5 and "dusty airmasses" $\left(\mathrm{FMF}_{\text {scat }}<0.3\right)$ are more common. Measurements aboard the NASA DC-8 over the North Pacific during INTEX-B (Spring 2006) and aboard the NSF/NCAR C-130 off the US west-coast during IMPEX (Spring, 2006) are qualitatively very similar. Both are influenced by sea salt below $900 \mathrm{mb}$, show "fine-mode dominated" $\left(\mathrm{FMF}_{\text {scat }}>0.6\right)$ or mixed airmass types up to $700 \mathrm{mb}$ and then become more heavily influenced by mixed airmass types above $700 \mathrm{mb}$ due to the long-range transport of Asian pollution and dust. In contrast measurements over North America east of $100^{\circ} \mathrm{W}$ longitude during INTEX-NA (Summer, 2004) show a very low frequency of airmasses that contain supermicrometer dust. Those INTEX-NA samples that did contain dust (rather than sea salt near the surface) were either fresh urban plumes, or located in the US Southwest where airmasses contained traces of Saharan rather than Asian dust. During ARCTAS the NASA DC- 8 spent the most time in the High Arctic whereas the two P-3B's spent most time sampling near Alaska. The ARCTAS DC-8 FMF scat profile also suffers from low sample numbers due to malfunction of the submicrometer nephelometer. However, the data still indicate a greater proprtion of "mixed" airmass types were found above $700 \mathrm{mb}$. The ARCTAS P-3B data indicate that fine mode dominated and mixed airmass types are comparable in number below $\sim 700 \mathrm{mb}$ but that mixed and even dusty airmass types become more prevalent in the middle to upper free troposphere. Thus, the ARCTAS/ARCPAC data support the hypothesis that Western Arctic airmasses are heavily influenced by emissions of Asian Dust transported across the Pacific after lofting by mid-latitude cyclones over Central Asia, East Asia and the Eastern North Pacific (Fuelberg et al., 2010; Stohl, 2006).

In an attempt to derive the MAE for supermicrometer dust, an analysis similar to that conducted for light absorbing carbon was undertaken. Despite the ubiquity of supermicrometer aerosol over the Western Arctic, the low absorption efficiency of dust and the high noise levels of the PSAP's make an accurate determination of the dust MAE difficult. Figure 11 plots $470 \mathrm{~nm}$ (top) and $530 \mathrm{~nm}$ (bottom) supermicrometer absorption versus dust mass assuming a dust density of $2.06 \mathrm{~g} \mathrm{~cm}^{-1}$. The data are color coded by supermicrometer mass fraction (top) and scattering Ångström exponent (bottom). In Fig. 11 all available data are plotted as open circles. Because of the high PSAP noise levels and the potential influence of absorption by non-dust species the data were heavily stratified by choosing data with a supermicrometer mass fraction $>0.75$ or a scattering Ångström exponent of less than 1.0. Sea salt was eliminated by restricting the analysis to data with absorption Ångström exponents greater than 1.5. The data retained for use ( $N=94$ at $300 \mathrm{~s})$ in the regressions are plotted as filled circles. Regressions based on the subset 

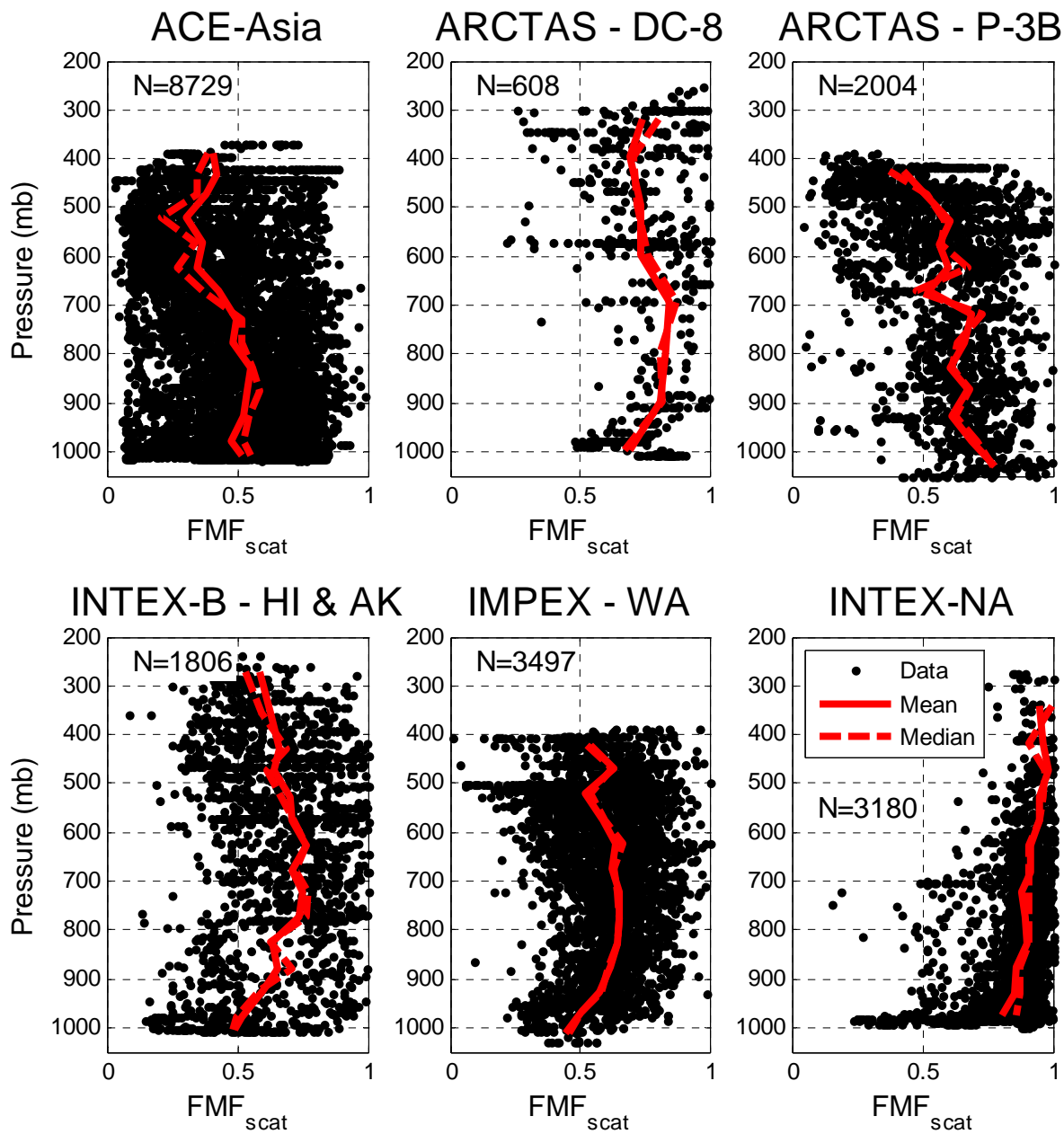

Fig. 10. Vertical profiles of the fine mode fraction of scattering $\left(\mathrm{FMF}_{\mathrm{scat}}\right)$ measured in-situ via aircraft during recent NASA and NSF-funded airborne field campaigns. Data points $(\mathrm{N})$ are restricted to cases where total scattering is greater than $3 \mathrm{Mm}^{-1}$ to eliminate ratios computed from low signal-to-noise scattering values.

of data result in MAE estimates of $0.034 \mathrm{~m}^{2} \mathrm{~g}^{-1}$ at $470 \mathrm{~nm}$, and $0.017 \mathrm{~m}^{2} \mathrm{~g}^{-1}$ at $530 \mathrm{~nm}$. Even after heavy stratification the regressions statistics remain poor $\left(R^{2}=0.29,0.13\right)$ but the slopes differ significantly from zero with $95 \%$ confidence intervals for the slopes of $0.023-0.046 \mathrm{~m}^{2} \mathrm{~g}^{-1}$, and 0.008 $0.027 \mathrm{~m}^{2} \mathrm{~g}^{-1}$ respectively.

Yang et al. (2009), report an $\mathrm{MAE}_{470}$ for dust of $0.050 \mathrm{~m}^{2} \mathrm{~g}^{-1}$, greater than our highly uncertain estimate of $0.034 \mathrm{~m}^{2} \mathrm{~g}^{-1}$ and slightly greater than our $95 \%$ confidence interval. Reported $\mathrm{MAE}_{530}$ values for Asian dust range between 0.009 and $0.034 \mathrm{~m}^{2} \mathrm{~g}^{-1}$ (Clarke et al., 2004; Yang et al., 2009). These are plotted as dashed (C04) and solid (Y09) black lines in Fig. 11 and roughly bracket the $95 \%$ CI of our estimate.

\subsection{Relative contributions of sources and absorbing species to light absorption over the Western Arctic}

The efficacy of radiative forcing by $\mathrm{BC}, \mathrm{BrC}$ and mineral dust over Polar Regions depends on their vertical distribution in the atmosphere. Although BC is the dominant absorber, its vertical distribution differs from that of dust and from non-absorbing sea salt. Furthermore, the strong wavelength dependence of both brown carbon and dust mean that the proportion of light absorption due to these species will also vary as a function of solar wavelength. Thus it is useful to compare the vertical distribution of the relative contribution from each source and species relative to absorption from all sources.

The first panel of Fig. 12 summarize the mean and median mass concentration profiles for BC over the Western Arctic. The ARCTAS/ARCPAC measurements show that black carbon peaks in the middle troposphere between $\sim 2$ and $6 \mathrm{~km}$ 

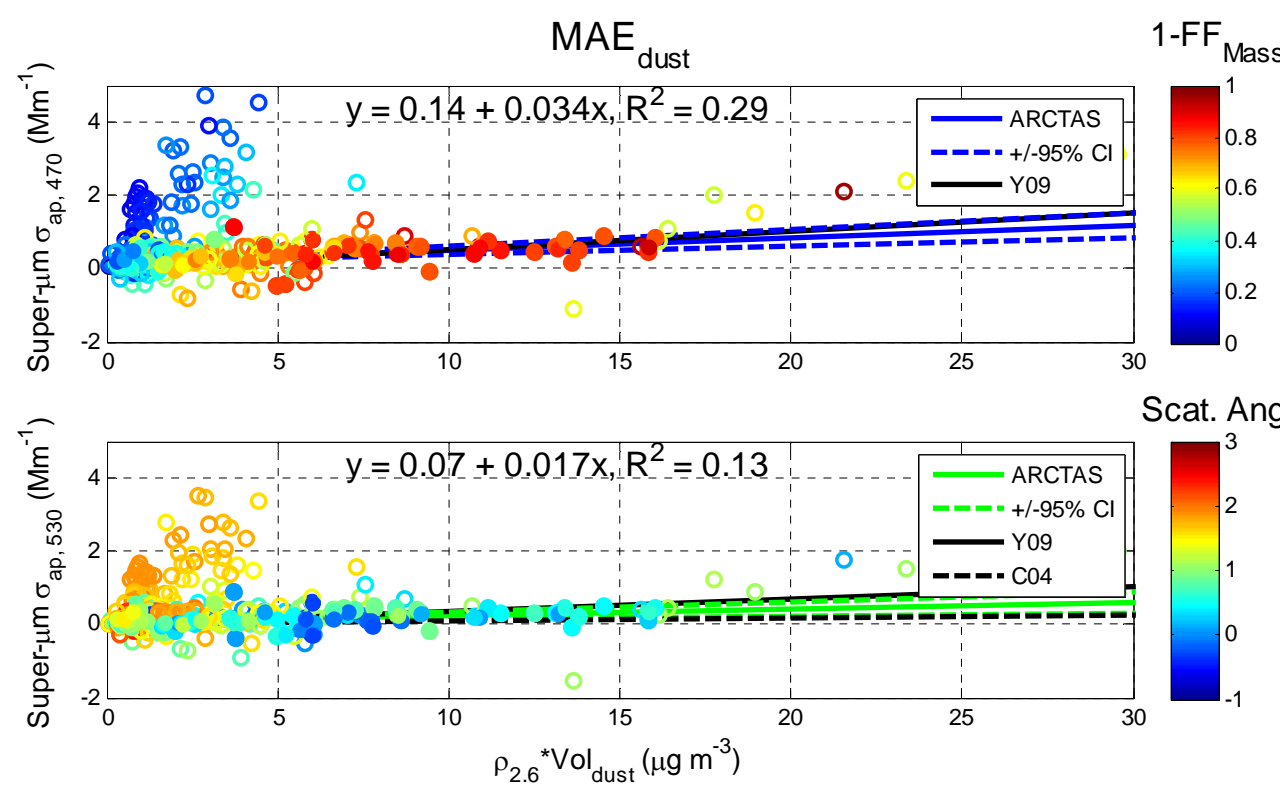

Fig. 11. Estimate for the MAE of supermicrometer dust at $470 \mathrm{~nm}$ (top) and $530 \mathrm{~nm}$ (bottom). Data were heavily stratified (solid symbols) so as to include only samples that were dominated by dust. Solid blue and green lines are the regressions, dashed are the $95 \%$ confidence intervals for the slope. Yang et al. (2007) (solid black) and Clarke et al. (2004) (dashed black), are included for comparison.
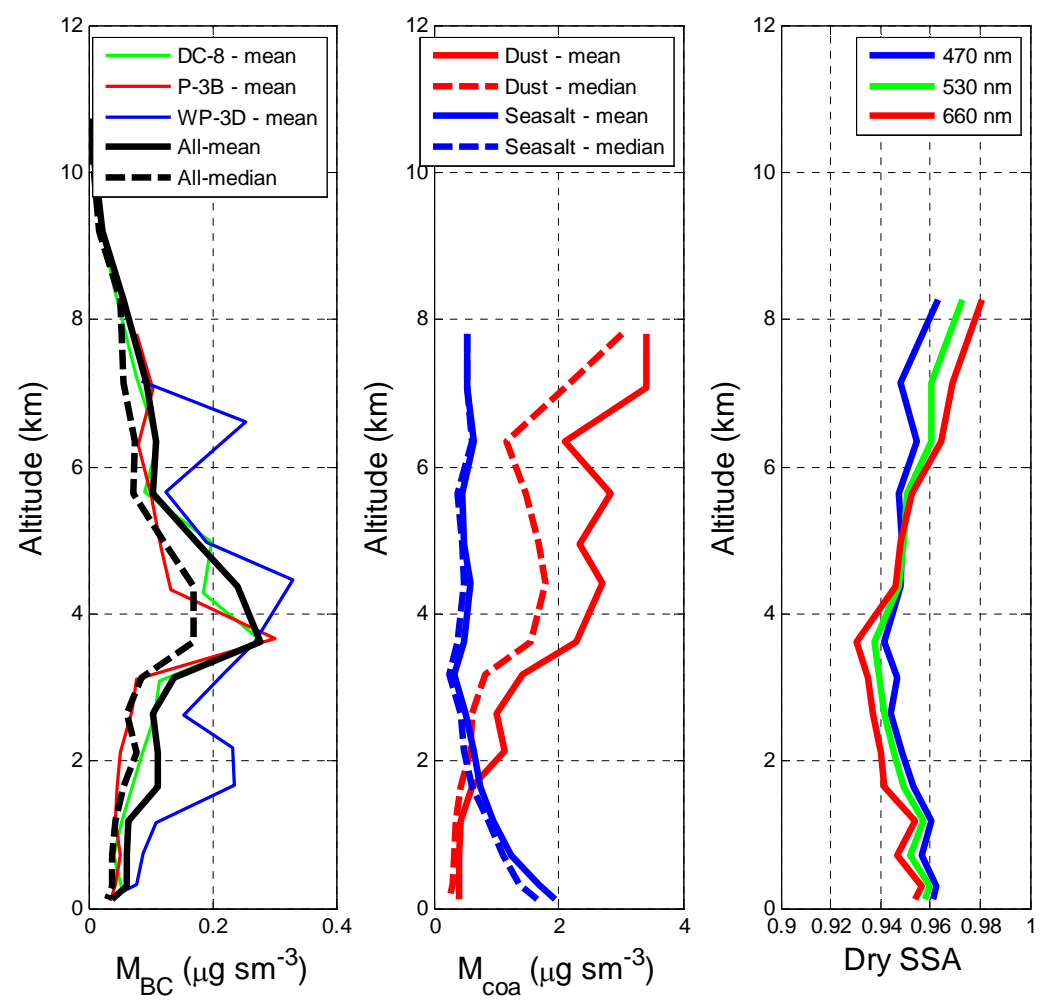

Fig. 12. Aircraft specific, and campaign averaged vertical profiles of (left) black carbon mass, (middle) classified supermicrometer aerosol mass - dust (red) and sea salt (blue), and (right) total dry single scattering albedo at 470, 530 and 660 nm wavelengths. 
Table 5. Summary of vertical profiles for black carbon mass, submicrometer aerosol mass, refractory submicrometer aerosol mass, as well as supermicrometer mineral dust and sea salt aerosol mass. Statistics include mean, median and standard deviations calculated from all available 1-min averaged data measured onboard the NASA DC-8, P-3B and NOAA WP-3D during ARCTAS/ARCPAC.

\begin{tabular}{|c|c|c|c|c|c|c|c|c|c|c|c|c|c|c|c|}
\hline \multirow{2}{*}{$\begin{array}{l}\text { Altitude }(\mathrm{km}) \\
\text { mean }\end{array}$} & \multicolumn{3}{|c|}{$\begin{array}{l}\text { Black Carbon Mass } \\
\qquad\left(\mu \mathrm{g} \mathrm{m}^{-3}\right)\end{array}$} & \multicolumn{3}{|c|}{$\begin{array}{l}\text { Submicrometer Mass } \\
\qquad\left(\mu \mathrm{g} \mathrm{m}^{-3}\right) \rho=1.6\end{array}$} & \multicolumn{3}{|c|}{$\begin{array}{l}\text { Refractory Sub. Mass } \\
\qquad\left(\mu \mathrm{g} \mathrm{m}^{-3}\right) \rho=1.3\end{array}$} & \multicolumn{3}{|c|}{$\begin{array}{c}\text { Dust Mass } \\
\left(\mu \mathrm{g} \mathrm{m}^{-3} \rho=2.20\right) \rho=2.06\end{array}$} & \multicolumn{3}{|c|}{$\begin{array}{l}\text { Sea salt Mass } \\
\quad\left(\mu \mathrm{g} \mathrm{m}^{-3}\right)\end{array}$} \\
\hline & mean & median & stdev & mean & median & stdev & mean & median & stdev & mean & median & stdev & mean & median & stdev \\
\hline 10.7 & 0.002 & 0.001 & 0.004 & & & & & & & & & & & & \\
\hline 9.2 & 0.023 & 0.017 & 0.019 & & & & & & & & & & & & \\
\hline 8.3 & 0.057 & 0.052 & 0.026 & & & & & & & & & & & & \\
\hline 7.1 & 0.093 & 0.057 & 0.117 & 1.4 & 0.77 & 2.0 & 0.47 & 0.28 & 0.68 & 3.4 & 2.2 & 3.9 & 0.55 & 0.54 & 0.62 \\
\hline 6.3 & 0.110 & 0.075 & 0.099 & 1.5 & 1.3 & 1.6 & 0.39 & 0.23 & 0.50 & 2.1 & 1.2 & 3.2 & 0.63 & 0.62 & 0.95 \\
\hline 5.6 & 0.105 & 0.073 & 0.102 & 2.8 & 1.6 & 2.6 & 0.35 & 0.24 & 0.33 & 2.8 & 1.5 & 4.5 & 0.45 & 0.39 & 0.71 \\
\hline 5.0 & 0.176 & 0.123 & 0.168 & 4.7 & 3.8 & 4.2 & 0.50 & 0.33 & 0.73 & 2.3 & 1.7 & 3.0 & 0.49 & 0.46 & 0.63 \\
\hline 4.4 & 0.241 & 0.169 & 0.235 & 7.1 & 4.7 & 7.7 & 0.54 & 0.39 & 0.62 & 2.7 & 1.8 & 2.9 & 0.58 & 0.48 & 0.63 \\
\hline 3.6 & 0.277 & 0.171 & 0.288 & 6.2 & 2.1 & 8.9 & 1.94 & 0.52 & 3.45 & 2.3 & 1.6 & 2.2 & 0.47 & 0.37 & 0.46 \\
\hline 3.1 & 0.137 & 0.086 & 0.155 & 4.1 & 1.5 & 6.4 & 0.46 & 0.23 & 0.63 & 1.4 & 0.82 & 1.6 & 0.35 & 0.25 & 0.40 \\
\hline 2.6 & 0.103 & 0.061 & 0.118 & 2.5 & 1.5 & 3.6 & 0.26 & 0.17 & 0.36 & 1.0 & 0.61 & 1.3 & 0.52 & 0.42 & 0.69 \\
\hline 2.1 & 0.112 & 0.077 & 0.122 & 3.8 & 3.1 & 4.4 & 0.26 & 0.18 & 0.29 & 1.1 & 0.57 & 1.5 & 0.64 & 0.50 & 0.86 \\
\hline 1.6 & 0.111 & 0.058 & 0.136 & 4.5 & 1.7 & 5.6 & 0.27 & 0.22 & 0.22 & 0.61 & 0.44 & 0.61 & 0.74 & 0.60 & 0.74 \\
\hline 1.2 & 0.065 & 0.044 & 0.067 & 2.6 & 2.0 & 2.2 & 0.30 & 0.23 & 0.28 & 0.44 & 0.36 & 0.37 & 0.94 & 0.87 & 0.79 \\
\hline 0.73 & 0.063 & 0.039 & 0.058 & 2.7 & 2.2 & 2.0 & 0.43 & 0.40 & 0.30 & 0.40 & 0.31 & 0.39 & 1.2 & 1.1 & 1.2 \\
\hline 0.30 & 0.061 & 0.039 & 0.065 & 2.8 & 2.1 & 2.0 & 0.40 & 0.30 & 0.33 & 0.39 & 0.30 & 0.33 & 1.7 & 1.4 & 1.4 \\
\hline 0.13 & 0.037 & 0.030 & 0.042 & 1.7 & 1.5 & 0.83 & 0.57 & 0.30 & 0.54 & 0.40 & 0.26 & 0.41 & 2.0 & 1.6 & 2.0 \\
\hline
\end{tabular}

with values in excess of $0.1 \mu \mathrm{g} \mathrm{s} \mathrm{m}^{-3}$. The second panel summarizes the vertical distribution of supermicrometer mass after classifying these aerosol as either dust or sea salt. This classification is accomplished by using data from the PALMS instrument (Froyd et al., 2009) to separate the P-3B and WP3D supermicrometer number distributions into aerosol types, and then applying realistic assumptions for the shape of lognormal dust and sea salt number distributions over the North Pacific (number median diameter, $\mathrm{NMD}_{\mathrm{DU}}=0.65 \mu \mathrm{m}$, geometric standard deviation, $\sigma_{\mathrm{g}, \mathrm{DU}}=2.0 ; \mathrm{NMD}_{\mathrm{SS}}=0.40 \mu \mathrm{m}$, $\sigma_{\mathrm{g}, \mathrm{SS}}=2.15$ ) (McNaughton, 2008). These number distributions are then converted to volume distributions, the integrals multiplied by appropriate dry bulk densities $\left(\rho_{\mathrm{DU}}=2.06\right.$ and $\rho_{\mathrm{SS}}=2.20 \mathrm{~g} \mathrm{~cm}^{-3}$ ), and the statistics summarized to construct the vertical profiles in Fig. 12. As indicated, mineral dust concentrations greater than $2 \mu \mathrm{g} \mathrm{cm}^{-3}$ are common above $4 \mathrm{~km}$ and decrease linearly to less than $0.5 \mu \mathrm{g} \mathrm{sm}^{-3}$ at the surface. Sea salt is most common below $\sim 1 \mathrm{~km}$ but was detected throughout the FT by the PALMS instrument. Table 5 contains summary statistics for the vertical profiles of aerosol mass measured during ARCTAS/ARCPAC including mean, median and standard deviations of BC mass, submicrometer mass, submicrometer refractory mass $\left(420^{\circ} \mathrm{C}\right.$, $\tau=0.1 \mathrm{~s}$ ), and supermicrometer mineral dust and sea salt mass. An estimate of $\mathrm{BrC}$ mass can be obtained by subtracting $\mathrm{BC}$ mass from submicrometer refractory mass.

The third panel of Fig. 12 plots vertical profiles of aerosol single scattering albedo at 470, 530 and $660 \mathrm{~nm}$ wavelengths. Low scattering Ångström exponent but high absorbing Ångström exponent by Asian dust at high altitude leads to lower $470 \mathrm{~nm}$ than $660 \mathrm{~nm}$ SSA's between 6 and
$8 \mathrm{~km}$. In the lower free troposphere $(2-6 \mathrm{~km})$, dust mass is decreasing as black carbon concentrations, especially from BB emissions, are reaching their peak values. Here the SSA's are equal at each wavelength. Near the surface, we observe the lowest masses of LAC (mostly urban/industrial emissions) and enhanced scattering due to sea salt aerosol. The result is higher dry SSA's that increase at shorter wavelengths, an effect that will be magnified in the ambient atmospheric environment due to high RH in/near the boundary layer. Table 6 contains summary statistics for dry aerosol optical properties measured during ARCTAS including total extinction, column aerosol optical depth (AOD), single scattering albedo and extinction-weight column SSA values at 470,530 and $660 \mathrm{~nm}$. ARCPAC extinction values are not included as they are submicrometer measurements only. However, a comparison between the NASA DC-8 plus $\mathrm{P}-3 \mathrm{~B}$ submicrometer extinction values and submicrometer extinction for all three aircraft (i.e. including the NOAA WP-3D values) is of interest because the NOAA WP-3D sampled a much higher proportion of $\mathrm{BB}$ influenced airmasses (Tables 1-3). Submicrometer $\mathrm{AOD}_{530}$ values for the NASA aircraft average 0.12 (median $=0.08$ ) with an extinction weighted column $\mathrm{SSA}_{530}$ value of $0.94 \pm 0.5$. The submicrometer $\mathrm{AOD}_{530}$ values computed from the average of all three aircraft average 0.16 (median $=0.10$ ) with an $\mathrm{SSA}_{530}$ value of $0.95 \pm 0.04$. These values can be compared to the total $\mathrm{AOD}_{530}$ and $\mathrm{SSA}_{530}$ values from the NASA aircraft which averaged 0.15 (median $=0.10$ ), and $0.95 \pm 0.3$. Thus, the presence of the intense but episodic BB plumes observed during ARCTAS/ARCPAC has increased the column AOD values by $\sim 1 / 3$ while potentially increasing the 
Table 6. Summary of vertical profiles for total light extinction and aerosol single scattering albedo at 470,530 and $660 \mathrm{~nm}$ wavelengths. Statistics include mean, median and standard deviations from all available 1-min averaged data measured onboard the NASA DC-8, P-3B during ARCTAS. Column dry aerosol optical depth (AOD) and SSA values are weighted by extinction.

\begin{tabular}{|c|c|c|c|c|c|c|c|c|c|c|c|c|c|c|c|}
\hline \multirow{2}{*}{$\begin{array}{l}\text { Altitude }(\mathrm{km}) \\
\text { mean }\end{array}$} & \multicolumn{3}{|c|}{$\begin{array}{l}\text { Total } 470 \mathrm{~nm} \text { Extinction } \\
\qquad\left(\mathrm{Mm}^{-1}\right)\end{array}$} & \multicolumn{3}{|c|}{$\begin{array}{l}\text { Total } 530 \mathrm{~nm} \text { Extinction } \\
\left(\mathrm{Mm}^{-1}\right)\end{array}$} & \multicolumn{3}{|c|}{$\begin{array}{c}\text { Total } 660 \mathrm{~nm} \text { Extinction } \\
\left(\mathrm{Mm}^{-1}\right)\end{array}$} & \multicolumn{2}{|c|}{ Total SSA at $470 \mathrm{~nm}$} & \multicolumn{2}{|c|}{ Total SSA at $530 \mathrm{~nm}$} & \multicolumn{2}{|c|}{ Total SSA at $660 \mathrm{~nm}$} \\
\hline & mean & median & stdev & mean & median & stdev & mean & median & stdev & mean & stdev & mean & stdev & mean & stdev \\
\hline 10.7 & 4.8 & 4.8 & 1.6 & 2.6 & 2.5 & 1.1 & 2.3 & 2.2 & 1.4 & & & & & & \\
\hline 9.2 & 6.9 & 6.5 & 3.9 & 4.0 & 3.6 & 2.7 & 4.6 & 3.7 & 3.3 & & & & & & \\
\hline 8.3 & 12 & 10 & 8.5 & 11 & 9.3 & 7.6 & 9.1 & 7.7 & 6.9 & 0.96 & 0.03 & 0.97 & 0.02 & 0.98 & 0.03 \\
\hline 7.1 & 19 & 11 & 31 & 16 & 9.8 & 25 & 13 & 7.7 & 18 & 0.95 & 0.03 & 0.96 & 0.03 & 0.97 & 0.03 \\
\hline 6.3 & 18 & 11 & 25 & 15 & 9.5 & 20 & 11 & 6.8 & 14 & 0.95 & 0.04 & 0.96 & 0.04 & 0.96 & 0.05 \\
\hline 5.6 & 17 & 11 & 21 & 13 & 8.7 & 17 & 9.4 & 6.3 & 12 & 0.95 & 0.03 & 0.95 & 0.03 & 0.95 & 0.04 \\
\hline 5.0 & 37 & 18 & 73 & 28 & 14 & 61 & 19 & 9.7 & 47 & 0.95 & 0.04 & 0.95 & 0.04 & 0.95 & 0.04 \\
\hline 4.4 & 34 & 16 & 58 & 26 & 12 & 44 & 17 & 8.8 & 28 & 0.95 & 0.03 & 0.95 & 0.03 & 0.95 & 0.04 \\
\hline 3.6 & 75 & 25 & 129 & 54 & 18 & 95 & 34 & 12.4 & 58 & 0.94 & 0.03 & 0.94 & 0.03 & 0.93 & 0.05 \\
\hline 3.1 & 22 & 13 & 29 & 16 & 9.6 & 21 & 11 & 6.7 & 13 & 0.95 & 0.03 & 0.94 & 0.04 & 0.93 & 0.05 \\
\hline 2.6 & 17 & 14 & 17 & 14 & 10 & 26 & 8.4 & 7.1 & 8.1 & 0.94 & 0.03 & 0.94 & 0.04 & 0.94 & 0.05 \\
\hline 2.1 & 15 & 12 & 13 & 11 & 8.8 & 10 & 7.3 & 6.0 & 6.5 & 0.95 & 0.03 & 0.95 & 0.04 & 0.94 & 0.05 \\
\hline 1.6 & 13 & 13 & 12 & 10 & 9.5 & 9.3 & 6.6 & 6.2 & 6.5 & 0.95 & 0.02 & 0.95 & 0.03 & 0.94 & 0.04 \\
\hline 1.2 & 16 & 15 & 13 & 11 & 11 & 9.4 & 7.8 & 7.3 & 6.0 & 0.96 & 0.02 & 0.96 & 0.03 & 0.95 & 0.03 \\
\hline 0.73 & 17 & 16 & 11 & 13 & 11 & 7.9 & 8.5 & 7.8 & 5.0 & 0.96 & 0.03 & 0.95 & 0.03 & 0.95 & 0.04 \\
\hline 0.30 & 17 & 16 & 7.0 & 13 & 12 & 5.4 & 8.9 & 8.4 & 4.0 & 0.96 & 0.02 & 0.96 & 0.02 & 0.96 & 0.02 \\
\hline 0.13 & 16 & 14 & 6.7 & 12 & 10 & 5.3 & 8.7 & 7.1 & 4.3 & 0.96 & 0.02 & 0.96 & 0.02 & 0.95 & 0.03 \\
\hline AOD \& SSA & 0.20 & 0.13 & & 0.15 & 0.10 & & 0.11 & 0.07 & & 0.95 & 0.03 & 0.95 & 0.03 & 0.95 & 0.04 \\
\hline
\end{tabular}

column SSA values by 0.01 ; the result of typically higher SSA for BB aerosol at $530 \mathrm{~nm}$ compared to $530 \mathrm{~nm} \mathrm{SS}$ for urban/industrial emissions.

There are too few dust-free samples to calculate a robust vertical distribution of submicrometer non-BC refractory mass (i.e. BrC). To calculate this quantity we instead use the average ratio of $\mathrm{BC}$ to submicrometer refractory mass $(\mathrm{BC} /(\mathrm{BrC}+\mathrm{BC}))$ to estimate $\mathrm{BrC}$ mass, restricting our analysis to cases where $\mathrm{FMF}_{\text {scat }}>0.6$. In urban/industrial airmasses the ratio of black carbon to submicrometer nondust refractory mass is approximately 0.25 (0.27 in Clarke et al., 2007; 0.23 during ARCTAS). In biomass burning plumes this ratio is closer to 0.15 (0.13 in (Clarke et al., 2007; 0.17 during ARCTAS). We can then use mass profiles of BC and dust to separate the contributions of each absorbing species at 470 and $530 \mathrm{~nm}$ wavelengths. Based on ARCTAS/ARCPAC results at $470 \mathrm{~nm}$ we assume an $\mathrm{MAE}_{\mathrm{BC}}$ of $11.2 \mathrm{~m}^{2} \mathrm{~g}^{-1}$, an $\mathrm{MAE}_{\mathrm{BrC}}$ value of $0.83 \mathrm{~m}^{2} \mathrm{~g}^{-1}$, and an $\mathrm{MAE}_{\text {Dust }}$ of $0.034 \mathrm{~m}^{2} \mathrm{~g}^{-1}$. At $530 \mathrm{~nm}$ we use MAE values of $9.5,0.27$ and $0.017 \mathrm{~m}^{2} \mathrm{~g}^{-1}$ for each species.

The solid blue and green lines in Fig. 13 plot the relative contribution of absorption by LAC to total absorption at $470 \mathrm{~nm}$ (left) and $530 \mathrm{~nm}$ (right) wavelengths. The figure further separates the contributions from the two main sources of anthropogenic absorbing aerosol - urban/industrial (red lines), biomass burning (black lines) - and breaks the LAC contribution into the fraction of total absorption from black carbon (solid red, black) and brown carbon (dashed red, black) at both wavelengths.

Above $6 \mathrm{~km}$ the contribution of mineral dust to total light absorption is significant, and constitutes $4-12 \%$ or $3-8 \%$ of absorption at 470 and $530 \mathrm{~nm}$ wavelengths respectively. At
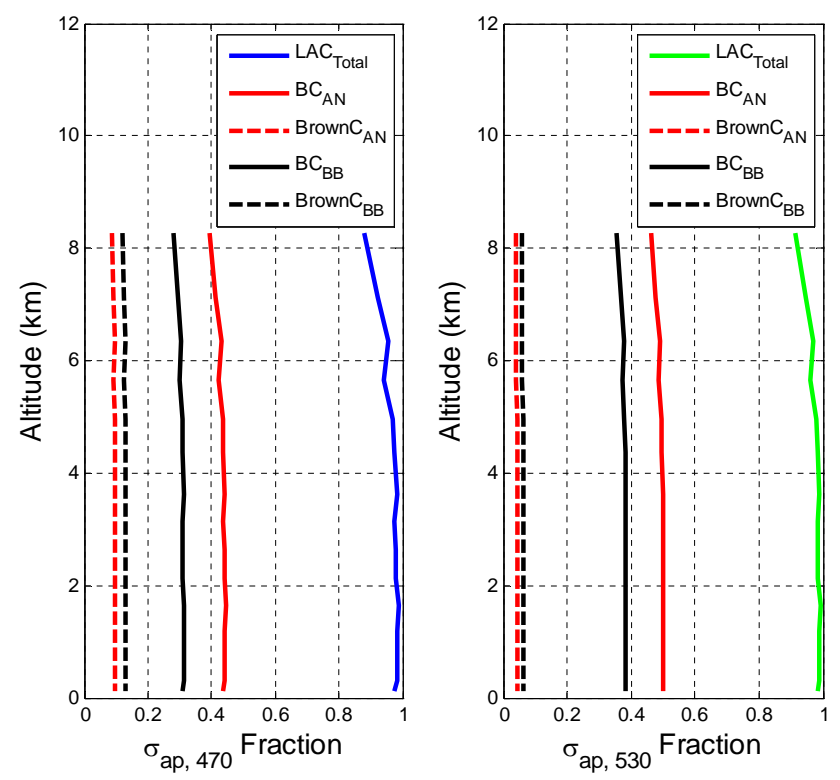

Fig. 13. Relative contributions of light absorbing carbon to total absorption as a function of altitude over the Western Arctic at $470 \mathrm{~nm}$ (left) and $530 \mathrm{~nm}$ (right) wavelengths. Contributions by black carbon (solid lines) and brown carbon (dashed) are further separated by their sources, urban/industrial emissions (red), and emissions from biomass burning (black).

these altitudes, light absorption by $\mathrm{BrC}$ from urban/industrial emissions average $9 \%(470 \mathrm{~nm})$ and $4 \%(530 \mathrm{~nm})$ of total light absorption, whereas absorption by $\mathrm{BrC}$ from biomass burning emissions accounts for $12 \%$ and $6 \%$ of total light absorption at each wavelength. Thus when combined, light 
absorption by $\mathrm{BrC}$ from anthropogenic sources is responsible for a higher proportion of total light absorption than nominally "natural" sources of mineral dust. Below $6 \mathrm{~km}$ the contribution by dust to total light absorption is even lower. LAC from urban/industrial sources constitute $51-54 \%$ of total light absorption, while LAC from BB emissions account for $42-45 \%$ of light absorption by aerosol. Thus the 2008 ARCTAS/ARCPAC results show that largely anthropogenic sources of LAC account for 94-99\% of total light absorption at $470 \mathrm{~nm}$, and $96-99 \%$ of total light absorption at $530 \mathrm{~nm}$ in the atmosphere below $6 \mathrm{~km}$ over the Western Arctic.

Future model simulations should seek to replicate the ARCTAS/ARCPAC vertical profiles of aerosol optical properties, specifically the contributions of $\mathrm{BC}, \mathrm{BrC}$, mineral dust and sea salt to total extinction and single scattering albedo, in order to determine the effects of these man-made absorbing aerosol on radiative budget of the entire Arctic domain compared to radiative forcing by dust alone in an unperturbed pre-industrial Arctic atmosphere.

\section{Conclusions}

In April of 2008 NASA's ARCTAS field campaign and NOAA's ARCPAC field campaign deployed research aircraft to the Western Arctic as part of POLARCAT, a core International Polar Year activity. Despite sampling similar geographic regions over a comparable period of time, a great deal of variability in combustion tracers (e.g. CO, light extinction, black carbon mass) was observed between the aircraft. The major cause of this variability was early, extensive agricultural and forest fires in Kazakhstan and Siberia in April 2008 (Fisher et al., 2010; Warneke et al., 2010). These plumes were sampled repeatedly by the NOAA WP-3D after 19 April, but sampled only briefly by the NASA DC- 8 and P-3B on 19 April.

After pooling the results from all three aircraft, we conclude that total light absorption over the Arctic was predominantly (88-99\%) due to light absorbing carbonaceous species derived from urban/industrial activities and biomass burning. Using the gas phase tracer acetonitrile and measurements of submicrometer aerosol chemistry, we were able to determine that airmasses dominated by biomass burning aerosols account for just $11-14 \%$ of the air volume sampled. However, these inefficient open combustion sources account for $42-47 \%$ of the total burden of black carbon over the Western Arctic, and were responsible for $39-44 \%$ of total light absorption; total light absorption being the sum of absorption by black carbon, brown carbon and mineral dust. Mineral dust was found to be ubiquitous throughout the troposphere of the Western Arctic. Mineral dust concentrations below $2 \mathrm{~km}$ averaged less than $0.5 \mu \mathrm{g} \mathrm{s} \mathrm{m}^{-3}$ increasing to values of 1.0 to $2.8 \mu \mathrm{g} \mathrm{s} \mathrm{m}^{-3}$ from 2 to $6 \mathrm{~km}$. However, below $6 \mathrm{~km}$ light absorption by carbonaceous species dominates the total absorption term so that dust accounts for only $1-3 \%$ of total light absorption at these altitudes. Above $6 \mathrm{~km}$ dust concentrations reach average values as high as $2.1-3.4 \mu \mathrm{g} \mathrm{s} \mathrm{m}^{-3}$. And though concentrations of LAC are decreasing above $6 \mathrm{~km}$, total light absorption remains dominated by LAC such that absorption by mineral dust accounts for only $4-12 \%$ or $3-9 \%$ of total absorption at $470 \mathrm{~nm}$ or $530 \mathrm{~nm}$ wavelengths respectively. Light absorption by brown carbon is a higher fraction of total absorption for BB plumes, accounting for $\sim 12 \%$ or $\sim 6 \%$ of total light absorption at 470 and $530 \mathrm{~nm}$ wavelengths. The corresponding contributions of total absorption by $\mathrm{BrC}$ derived from urban/industrial sources are $\sim 10 \%$ at $470 \mathrm{~nm}$ and $\sim 4 \%$ at $530 \mathrm{~nm}$.

Comparisons between intensive and extensive aerosol properties among the aircraft are excellent. Stratification of the data allowed us to derive mass absorption efficiencies for black carbon and brown carbon as a function of wavelength. At 470,530 and $660 \mathrm{~nm}$ the $\mathrm{MAE}_{\mathrm{BC}}$ values are $11.2 \pm 0.8$, $9.5 \pm 0.6$ and $7.4 \pm 0.7 \mathrm{~m}^{2} \mathrm{~g}^{-1}$. These estimates represent insitu values for dry atmospheric aerosol and are consistent with recent estimates of $35-80 \%$ enhancements in $530 \mathrm{~nm}$ absorption due to coating of pure black carbon particulate with clear or weakly absorbing coatings. Assuming that refractory mass measured in relatively dust free samples is dominated by refractory organic matter responsible for enhanced absorption at shorter wavelengths, we were able to estimate MAE values for brown carbon at 470 and $530 \mathrm{~nm}$ wavelengths of $0.83 \pm 0.15$ and $0.27 \pm 0.08 \mathrm{~m}^{2} \mathrm{~g}^{-1}$. These brown carbon MAE values are broadly consistent with recently reported data from the East-Asian source region. An attempt to derive the mass absorption efficiencies for Asian dust produced values of $0.034 \mathrm{~m}^{2} \mathrm{~g}^{-1}$ and $0.017 \mathrm{~m}^{2} \mathrm{~g}^{-1}$. However, these estimates are highly uncertain $(95 \% \mathrm{CI}$ of $0.023-0.046$ and $0.008-0.027 \mathrm{~m}^{2} \mathrm{~g}^{-1}$, with $R^{2}<0.29,0.13$ ) due to the limitations imposed by the filter-based PSAP instrument.

Recent modeling studies show black carbon is poorly simulated in the Arctic compared to its simulation at midlatitudes (Koch et al., 2009), that simulating organic aerosol is particularly complex (Kanakidou et al., 2005), and that there is high diversity among models predicting their optical properties globally (Kinne et al., 2006). The ARCTAS/ARCPAC results show that while total light absorption is dominated by black carbon, predominantly anthropogenic sources of brown carbon contribute a larger proportion of total light absorption than nominally natural sources of mineral dust. Above $6 \mathrm{~km}$ the proportion of total absorption by brown carbon at $470 \mathrm{~nm}$ wavelength can exceed that of mineral dust by factors of 2 to 5 even though mineral dust transported long range from East Asia has its highest concentrations at these altitudes. Below $6 \mathrm{~km}$ dust concentrations decrease while LAC concentration increase such that absorption by $\mathrm{BrC}$ can be $10-15$ times the absorption by dust and absorption by total LAC can be 50-100 times that of "natural' Asian dust.

The remote location, harsh environment, and prevailing meteorology over the short duration of ARCTAS/ARCPAC 
field campaigns, mean that the atmosphere of the Western Arctic likely remains critically undersampled. These factors preclude using the airborne data to evaluate seasonal or interannual variability - the role of models. Future investigations by climate modeling teams should seek to replicate the relative proportions of these absorbing species over the Western Arctic, if not their concentrations at these locations, in an effort to determine the effects of man-made emissions of absorbing aerosol on the radiation balance of the entire Arctic domain.

Acknowledgements. The authors would like to thank the NASA and NOAA support staff as well as the aircraft flight crews for their assistance in collecting this important data. We would also like to acknowledge Karl Froyd and the PALMS team for providing data critical to separating supermicrometer aerosol into dust and sea salt types. The lead author would like to thank the Association of Polar Early Career Scientists (APECS) for travel support to present these results at the International Polar Year Science Conference in Oslo Norway in June 2010. This work is funded under NASA and NOAA Grants: NASA NNX08AD39G and NSF/UCAR S05-39607 (JLJ and MJC).

Edited by: J. W. Bottenheim

\section{References}

ACIA: Impacts of a Warming Arctic: Arctic Climate Impact Assessment, Cambridge University Press, New York, USA, 2004.

Adler, G., Riziq, A. A., Erlick, C., and Rudich, Y.: Effect of intrinsic organic carbon on the optical properties of fresh diesel soot, Proc. Natl. Acad. Sci., 107(15), 6699-6704, doi:10.1073/pnas.0903311106, 2010.

Anderson, T. L. and Ogren, J. A: Determining aerosol radiative properties using a TSI 3563 integrating nephelometer, Aerosol Sci. Technol., 29, 57-69, doi:10.1080/02786829808965551, 1998.

Anderson, T. L., Masonis, S. J., Covert, D. S., Ahlquist, N. C., Howell, S. G., Clarke, A. D., and McNaughton, C. S.: Variability of aerosol optical properties derived from in situ aircraft measurements during ACE-Asia, J. Geophys. Res., 108(D23), 8647, doi:10.1029/2002jd003247, 2003.

Anderson, T. L., Covert, D. S., Wheeler, J. D., Harris, J. M., Perry, K. D., Trost, B. E., Jaffe, D. J., and Ogren, J. A.: Aerosol backscatter fraction and single scattering albedo: Measured values and uncertainties at a coastal station in the Pacific Northwest, J. Geophys. Res., 104(D21), 26793-26807, doi:10.1029/1999jd900172, 1999.

Andreae, M. O. and Gelencsr, A.: Black carbon or brown carbon? The nature of light-absorbing carbonaceous aerosols, Atmos. Chem. Phys., 6, 3131-3148, doi:10.5194/acp-6-3131-2006, 2006.

Arnott, W. P., Hamasha, K., Moosmuller, H., Sheridan, P. J., and Ogren, J. A.: Towards aerosol light-absorption measurements with a 7-wavelength aethalometer: Evaluation with a photoacoustic instrument and 3-wavelength nephelometer, Aerosol Sci. Technol., 39, 17-29, doi:10.1080/027868290901972, 2005.
Baumgardner, D., Kok, G., and Raga, G.: Warming of the Arctic lower stratosphere by light absorbing particles, Geophys. Res. Lett., 31(6), 1-4, L06117, doi:10.1029/2003GL018883, 2004.

Bokoye, A. I., Royer, A., O’Neill, N. T., and McArthur, L. J. B.: A North American Arctic aerosol climatology using ground-based sunphotometry, Arctic, 55(3), 215-228, 2002.

Bond, T. C., Anderson, T. L., and Campbell, D.: Calibration and intercomparison of filter-based measurements of visible light absorption by aerosols, Aerosol Sci. Technol., 30(6), 582-600, 1999.

Bond, T. C., Habib, G., and Bergstrom, R. W.: Limitations in the Enhancement of Visible Light Absorption due to Mixing State, J. Geophys. Res., 111, D20211, doi:10.1029/2006JD007315, 2006.

Bourdages, L., Duck, T. J., Lesins, G., Drummond, J. R., and Eloranta, E. W.: Physical properties of High Arctic tropospheric particles during winter, Atmos. Chem. Phys., 9, 6881-6897, doi:6810.5194/acp-6889-6881-2009, 2009.

Brock, C. A., Schroder, F., Karcher, B., Petzold, A., Busen, R., and Fiebig, M.: Ultrafine particle size distributions measured in aircraft exhaust plumes, J. Geophys. Res., 105(D21), 26555-26567, doi:10.1029/2000JD900360, 2000.

Brock, C. A., Sullivan, A. P., Peltier, R. E., Weber, R. J., Wollny, A., de Gouw, J. A., Middlebrook, A. M., Atlas, E. L., Stohl, A., Trainer, M. K., Cooper, O. R., Fehsenfeld, F. C., Frost, G. J., Holloway, J. S., Hübler, G., Neuman, J. A., Ryerson, T. B., Warneke, C., and Wilson, J. C.: Sources of particulate matter in the northeastern United States in summer: 2. Evolution of chemical and microphysical properties, J. Geophys. Res., 113(D8), D08302, doi:10.1029/2007jd009241, 2008.

Brock, C. A., Cozic, J., Bahreini, R., Froyd, K. D., Middlebrook, A. M., McComiskey, A., Brioude, J., Cooper, O. R., Stohl, A., Aikin, K. C., de Gouw, J. A., Fahey, D. W., Ferrare, R. A., Gao, R.-S., Gore, W., Holloway, J. S., Hbler, G., Jefferson, A., Lack, D. A., Lance, S., Moore, R. H., Murphy, D. M., Nenes, A., Novelli, P. C., Nowak, J. B., Ogren, J. A., Peischl, J., Pierce, R. B., Pilewskie, P., Quinn, P. K., Ryerson, T. B., Schmidt, K. S., Schwarz, J. P., Sodemann, H., Spackman, J. R., Stark, H., Thomson, D. S., Thornberry, T., Veres, P., Watts, L. A., Warneke, C., and Wollny, A. G.: Characteristics, sources, and transport of aerosols measured in spring 2008 during the aerosol, radiation, and cloud processes affecting Arctic Climate (ARCPAC) Project, Atmos. Chem. Phys., 11, 2423-2453, doi:10.5194/acp-11-24232011, 2011.

Canagaratna, M. R., Jayne, J. T., Jimenez, J. L., Allan, J. D., Alfarra, M. R., Zhang, Q., Onasch, T. B., Drewnick, F., Coe, H., Middlebrook, A., Delia, A. E., Williams, L. R., Trimborn, A., Northway, M. J., DeCarlo, P. F., Kolb, C. E., Davidovits, P., and Worsnop, D. R.: Chemical and Microphysical Characterization of Ambient Aerosols with the Aerodyne Aerosol Mass Spectrometer, Mass Spectrom. Rev., 26, 185-222, doi:10.1002/mas.20115, 2007.

Cappa, C. D., Lack, D. A., Burkholder, J. B., and Ravishankara, A. R.: Bias in Filter-Based Aerosol Light Absorption Measurements Due to Organic Aerosol Loading: Evidence from Laboratory Measurements, Aerosol Sci. Technol., 42, 1022-1032, doi:10.1080/02786820802389277, 2008.

Clarke, A. D. and Kapustin, V. N.: Hemispheric Aerosol Vertical Profiles: Anthropogenic Impacts on Optical Depth and Cloud Nuclei, Science, 329(1488), doi:10.1126/science.1188838, 2010. 
Clarke, A. D. and Noone, K. J.: Soot in the Arctic Snowpack - a Cause for Perturbations in Radiative-Transfer, Atmos. Environ., 19(12), 2045-2053, 1985.

Clarke, A. D., Charlson, R. J., and Radke, L. F.: Airborne Observations of Arctic Aerosol .4. Optical-Properties of Arctic Haze, Geophys. Res. Lett., 11(5), 405-408, 1984.

Clarke, A. D., Shinozuka, Y., Kapustin, V. N., Howell, S., Huebert, B., Doherty, S., Anderson, T., Covert, D., Anderson, J., Hua, X., Moore II, K. G., McNaughton, C., Carmichael, G., and Weber, R.: Size distributions and mixtures of dust and black carbon aerosol in Asian outflow: Physiochemistry and optical properties, J. Geophys. Res., 109(D15), D15S09, doi:10.1029/2003jd004378, 2004.

Clarke, A. D., McNaughton, C., Kapustin, V., Shinozuka, Y., Howell, S., Dibb, J., Zhou, J., Anderson, B., Brekhovskikh, V., Turner, H., and Pinkerton, M.: Biomass burning and pollution aerosol over North America: Organic components and their influence on spectral optical properties and humidification response, J. Geophys. Res., 112(D12), D12S18, doi:10.1029/2006jd007777, 2007.

Crounse, J. D., DeCarlo, P. F., Blake, D. R., Emmons, L. K., Campos, T. L., Apel, E. C., Clarke, A. D., Weinheimer, A. J., McCabe, D. C., Yokelson, R. J., Jimenez, J. L., and Wennberg, P. O.: Biomass burning and urban air pollution over the Central Mexican Plateau, Atmos. Chem. Phys., 9, 4929-4944, doi:10.5194/acp-9-4929-2009, 2009.

de Gouw, J. A. and Jimenez, J. L.: Organic aerosols in the Earth's atmosphere, Environ. Sci. Technol., 43, 7614-7618, doi:10.1021/es9006004, 2009.

de Gouw, J. A. and Warneke, C.: Measurements of volatile organic compounds in the Earth's atmosphere using proton-transferreaction mass spectrometery, Mass Spectrom. Rev., 26, 223-257, doi:10.1002/mas.20119, 2007.

de Gouw, J. A., Cooper, O. R., Warneke, C., Hudson, P. K., Fehsenfeld, F. C., Holloway, J. S., Hubler, G., Nicks Jr., D. K., Nowak, J. B., Parrish, D. D., Ryerson, T. B., and Trainer, M.: Chemical composition of airmasses transported from Asia to the U.S. West Coast during ITCT 2K2: Fossil fuel combustion versus biomass-burning signatures, J. Geophys. Res., 109, D23S20, doi:10.1029/2003JD004202, 2004.

DeCarlo, P. F., Kimmel, R. E., Trimborn, A., Northway, M. J., Jayne, J. T., Aiken, A. C., Gonin, M., Fuhrer, K., Horvath, T., Docherty, K. S., Worsnop, D. R., and Jimenez, J. L.: Field-Deployable, High-Resolution, Time-of-Flight Aerosol Mass Spectrometer, Anal. Chem., 78, 8281-8289, doi:10.1021/ac061249n, 2006.

DeCarlo, P. F., Ulbrich, I. M., Crounse, J., de Foy, B., Dunlea, E. J., Aiken, A. C., Knapp, D., Weinheimer, A. J., Campos, T., Wennberg, P. O., and Jimenez, J. L.: Investigation of the sources and processing of organic aerosol over the Central Mexican Plateau from aircraft measurements during MILAGRO, Atmos. Chem. Phys., 10, 5257-5280, doi:10.5194/acp-10-52572010, 2010.

Dunlea, E. J., DeCarlo, P. F., Aiken, A. C., Kimmel, R. E., Peltier, R. E., Weber, R. J., Tomlinson, J. M., Collins, D. R., Shinozuka, Y., McNaughton, C. S., Howell, S. G., Clarke, A. D., Emmons, L. K., Apel, E. C., Pfister, G., van Donkelaar, A., Martin, R. V., Millet, D. B., Heald, C. L., and Jimenez J. L.: Evolution of Asian Aerosols during Transpacific Transport in INTEX-B, At- mos. Chem. Phys., 9, 7257-7287, doi:10.5194/acp-9-7257-2009, 2009.

Fisher, J. A., Jacob, D. J., Purdy, M. T., Kopacz, M., Le Sager, P., Carouge, C., Holmes, C. D., Yantosca, R. M., Batchelor, R. L., Strong, K., Diskin, G. S., Fuelberg, H. E., Holloway, J. S., Hyer, E. J., McMillan, W. W., Warner, J., Streets, D. G., Zhang, Q., Wang, Y., and Wu, S.: Source attribution and interannual variability of Arctic pollution in spring constrained by aircraft (ARCTAS, ARCPAC) and satellite (AIRS) observations of carbon monoxide, Atmos. Chem. Phys., 10, 977-996, doi:10.5194/acp-10-977-2010, 2010.

Flanner, M. G., Zender, C. S., Hess, P. G., Mahowald, N. M., Painter, T. H., Ramanathan, V., and Rasch, P. J.: Springtime warming and reduced snow cover from carbonaceous particles, Atmos. Chem. Phys., 9, 2481-2497, doi:10.5194/acp-9-24812009, 2009.

Fromm, M., Lindsey, D. T., Servranckx, R., Yue, G., Trickl, T., Sica, R., Doucet, P., and Godin-Beekmann, S.: The untold story of pyrocumulonimbus, B Am. Meteorol. Soc., 91(9), 1193-1209, doi:1110.1175/2010BAMS3004.1191, 2010.

Froyd, K. D., Murphy, D. M., Sanford, T. J., Thomson, D. S., Wilson, J. C., Pfister, L., and Lait, L.: Aerosol composition of the tropical upper troposphere, Atmos. Chem. Phys., 9, 4363-4385, doi:10.5194/acp-9-4363-2009, 2009.

Fuelberg, H. E., Harrigan, D. L., and Sessions, W.: A meteorological overview of the ARCTAS 2008 mission, Atmos. Chem. Phys., 10, 817-842, doi:10.5194/acp-10-817-2010, 2010.

Fuller, K., Malm, W. C., and Kriedenweiss, S. M.: Effects of mixing on extinction by carbonaceous particles, J. Geophys. Res., 104, 15941-15954, 1999.

Gong, S. L., Zhao, T. L., Sharma, S., Toom-Sauntry, D., Lavoue, D., Zhang, X. B., Leaitch, W. R., and Barrie, L. A.: Identification of trends and interannual varia bility of sulfate and black carbon in the Canadian High Arctic: 1981-2007, J. Geophys. Res., 115, D07305, doi:10.1029/2009JD01294, 20103.

Graber, E. R. and Rudich, Y.: Atmospheric HULIS: How humiclike are they? A comprehensive and critical review, Atmos. Chem. Phys., 6, 729-753, doi:10.5194/acp-6-729-2006, 2006.

Guan, H., Esswein, R., Lopez, J., Bergstrom, R., Warnock, A., Follette-Cook, M., Fromm, M., and Iraci, L. T.: A multidecadal history of biomass burning plume heights identified using aerosol index measurements, Atmos. Chem. Phys., 10, 64616469, doi:10.5194/acp-10-6461-2010, 2010.

Gyawali, M., Arnott, W. P., Lewis, K., and Moosmüller, H.: In situ aerosol optics in Reno, NV, USA during and after the summer 2008 California wildfires and the influence of absorbing and non-absorbing organic coatings on spectral light absorption, Atmos. Chem. Phys., 9, 8007-8015, doi:10.5194/acp-9-8007-2009, 2009.

Hansen, J. and Nazarenko, L.: Soot climate forcing via snow and ice albedos, Proc. Natl. Acad. Sci. USA, 101(2), 423-428, doi:10.1073/pnas.2237157100, 2004.

Haywood, J. M. and Shine, K. P.: The effect of anthropogenic sulfate and soot aerosol on the clear sky planetary radiation budget, Geophys. Res. Lett., 22(5), 603-606, 1995.

Hegg, Dean A., Warren, Stephen G., Grenfell, Thomas C., Sarah J Doherty, and Clarke, Antony D.: Sources of light-absorbing aerosol in arctic snow and their seasonal variation, Atmos. Chem. Phys., 10, 10923-10938, doi:10.5194/acp-10-10923-2010, 2010. 
Huebert, B. J., Bates, T., Russell, P. B., Shi, G., Kim, Y. J., Kawamura, K., Carmichael, G., and Nakajima, T.: An overview of ACE-Asia: Strategies for quantifying the relationships between Asian aerosols and their climatic impacts, J. Geophys. Res., 108(D23), 8633, doi:10.1029/2003jd003550, 2003.

Huebert, B. J., Bertram, T., Kline, J., Howell, S., Eatough, D., and Blomquist, B.: Measurements of organic and elemental carbon in Asian outflow during ACE-Asia from the NSF/NCAR C-130, J. Geophys. Res., 109(D19), D19S11, doi:10.1029/2004jd004700, 2004a.

Huebert, B. J., Howell, S. G., Covert, D., Bertram, T., Clarke, A., Anderson, J. R., Lafleur, B. G., Seebaugh, W. R., Wilson, J. C., Gesler, D., Blomquist, B., and Fox, J.: PELTI: Measuring the Passing Efficiency of an Airborne Low Turbulence Aerosol Inlet, Aerosol Sci. Technol., 38(8), 803-826, doi:10.1080/027868290500823, 2004b.

IPCC: Technical Summary, in Climate Change 2007: The Physical Science Basis. Contribution of Working Group I to the Fourth Assessment Report of the Intergovernmental Panel on Climate Change, edited by: Solomon, D. Q. S., Manning, M., Chen, Z., Marquis, M., Averyt, K. B., Tignor, M., and Miller, H. L., Cambridge University Press, Cambridge, UK and New York, NY, USA, 2007.

Ishii, S., Shibata, T., Nagai, T., Mizutani, K., Itabe, T., Hirota, M., Fujimoto, T., and Uchino, O.: Arctic haze and clouds observed by lidar during four winter seasons of 19931997 at Eureka Canada, Atmos. Environ., 33(16), 2459-2470, doi:10.1016/S1352-2310(98)00397-5, 1999.

Jacob, D. J., Crawford, J. H., Maring, H., Clarke, A. D., Dibb, J. E., Emmons, L. K., Ferrare, R. A., Hostetler, C. A., Russell, P. B., Singh, H. B., Thompson, A. M., Shaw, G. E., McCauley, E., Pederson, J. R., and Fisher, J. A.: The Arctic Research of the Composition of the Troposphere from Aircraft and Satellites (ARCTAS) mission: design, execution, and first results, Atmos. Chem. Phys., 10, 5191-5212, doi:10.5194/acp-10-5191-2010, 2010.

Kanakidou, M., Seinfeld, J. H., Pandis, S. N., Barnes, I., Dentener, F. J., Facchini, M. C., Van Dingenen, R., Ervens, B., Nenes, A., Nielsen, C. J., Swietlicki, E., Putaud, J. P., Balkanski, Y., Fuzzi, S., Horth, J., Moortgat, G. K., Winterhalter, R., Myhre, C. E. L., Tsigaridis, K., Vignati, E., Stephanou, E. G., and Wilson, J.: Organic aerosol and global climate modelling: a review, Atmos. Chem. Phys., 5, 1053-1123, doi:10.5194/acp-5-1053-2005, 2005.

Kinne, S., Schulz, M., Textor, C., Guibert, S., Balkanski, Y., Bauer, S. E., Berntsen, T., Berglen, T. F., Boucher, O., Chin, M., Collins, W., Dentener, F., Diehl, T., Easter, R., Feichter, J., Fillmore, D., Ghan, S., Ginoux, P., Gong, S., Grini, A., Hendricks, J., Herzog, M., Horowitz, L., Isaksen, I., Iversen, T., Kirkevg, A., Kloster, S., Koch, D., Kristjansson, J. E., Krol, M., Lauer, A., Lamarque, J. F., Lesins, G., Liu, X., Lohmann, U., Montanaro, V., Myhre, G., Penner, J., Pitari, G., Reddy, S., Seland, O., Stier, P., Takemura, T., and Tie, X.: An AeroCom initial assessment -optical properties in aerosol component modules of global models, Atmos. Chem. Phys., 6, 1815-1834, doi:10.5194/acp-6-1815-2006, 2006.

Kirchstetter, T. W., Novakov, T., and Hobbs, P. V.: Evidence that the spectral dependence of light absorption by aerosols is affected by organic carbon, J. Geophys. Res., 109, D21208, doi:10.1029/2004JD004999, 2004.
Kline, J., Huebert, B., Howell, S., Blomquist, B., Zhuang, J., Bertram, T., and Carrillo, J.: Aerosol composition and size versus altitude measured from the C-130 during ACE-Asia, J. Geophys. Res., 109(D19), D19S08, doi:10.1029/2004jd004540, 2004.

Koch, D., Schulz, M., Kinne, S., McNaughton, C., Spackman, J. R., Balkanski, Y., Bauer, S., Berntsen, T., Bond, T. C., Boucher, O., Chin, M., Clarke, A., De Luca, N., Dentener, F., Diehl, T., Dubovik, O., Easter, R., Fahey, D. W., Feichter, J., Fillmore, D., Freitag, S., Ghan, S., Ginoux, P., Gong, S., Horowitz, L., Iversen, T., Kirkevg, A., Klimont, Z., Kondo, Y., Krol, M., Liu, X., Miller, R., Montanaro, V., Moteki, N., Myhre, G., Penner, J. E., Perlwitz, J., Pitari, G., Reddy, S., Sahu, L., Sakamoto, H., Schuster, G., Schwarz, J. P., Seland, ., Stier, P., Takegawa, N., Takemura, T., Textor, C., van Aardenne, J. A., and Zhao, Y.: Evaluation of black carbon estimations in global aerosol models, Atmos. Chem. Phys., 9, 9001-9026, doi:10.5194/acp-9-9001-2009, 2009.

Kondo, Y., Sahu, L., Kuwata, M., Miyazaki, Y., Takegawa, N., Moteki, N., Imaru, J., Han, S., Nakayama, T., Kim Oang, N. T., Hu, M., Kim, Y. J., and Kita, K.: Stabilization of the Mass Absorption Cross Section of Black Carbon for Filter-Based Absorption Photometry by the use of a Heated Inlet, Aerosol Sci. Technol., 43, 741-756, doi:10.1080/02786820902889879, 2009.

Kondo, Y., Sahu, L., Moteki, N., Khan, F., Takegawa, N., Liu, X., Koike, M., and Miyakawa, T.: Consistency and traceability of black carbon measurements made by laser-induced incandescence, thermal-optical transmittance, and filter-based photoaborption techniques, Aerosol Sci. Technol., 45(2), 294-312, doi:10.1080/02786826.2010.533215, 2011.

Lack, D. A. and Cappa, C. D.: Impact of brown and clear carbon on light absorption enhancement, single scatter albedo and absorption wavelength dependence of black carbon, Atmos. Chem. Phys., 10, 4207-4220, doi:10.5194/acp-10-4207-2010, 2010.

Lack, D. A., Cappa, C. D., Covert, D. C., Baynard, T., Massoli, P., Sierau, B., Bates, T. S., Quinn, P. K., Lovejoy, E. R., and Ravishankara, A. R.: Bias in Filter-Based Aerosol Light Absorption Measurements Due to Organic Aerosol Loading: Evidence from Ambient Measurements, Aerosol Sci. Technol., 42, 1033-1041, doi:10.1080/02786820802389277, 2008.

Lafon, S., Sokolik, I., Rajot, J., Caquineau, S., and Gaudichet, A.: Characterization of iron oxides in mineral dust aerosols: Implications for light absorption, J. Geophys. Res., 111, D21207, doi:10.1029/2005JD007016, 2006.

Leaitch, W. R., Hoff, R. M., and MacPherson, J. I.: , Airborne and lidar measurements of aerosol and c loud particles in the troposphere over Alert Canada in April 1986, J. Atmos. Chem., 9(13), 187-211, doi:10.1007/BF00052832, 1989.

Li, Z., Chen, H., Cribb, M., Dickerson, R. R., Holben, B., Li, C., Lu, D., Luo, Y., Maring, H., Shi, G., Tsay, S. C., Wang, P., Wang, Y., Xia, X., Zheng, Y., Yuan, T., and Zhao, F.: Preface to special section on East Asian Studies of Tropospheric Aerosols: An International Regional Experiment (EAST-AIRE), J. Geophys. Res., 112, D22S00, doi:10.1029/2007JD008853, 2007.

Lindinger, W., Hansel, A., and Jordan, A.: Proton-transer-reaction mass spectrometry (PTR-MS) on-line monitoring of volatile organic compounds at pptv levels, Chemical Society Reviews, 27, 347-354, 1998.

Mader, B., Flagan, R. C., and Seinfeld, J. H.: Airborne measure- 
ments of atmospheric carbonaceous aerosols during ACE-Asia, J. Geophys. Res., 107, 4704, doi:10.1029/2002JD002221, 2002.

Mayol-Bracero, O. L., Gabriel, R., Andreae, M. O., Kirchstetter, T. W., Novakov, T., Ogren, J., Sheridan, P., and Streets, D. G.: Carbonaceous aerosols over the Indian Ocean during the Indian Ocean Experiment (INDOEX): Chemical characterization, optical properties, and probable sources, J. Geophys. Res., 107(D19), INX2 29-21-INX22 29-21, doi:10.1029/2000JD000039, 2002.

McNaughton, C. S.: Constraining climate model simulations of aerosol size distributoins over the North Pacific and North America using in-situ airborne measurements, $\mathrm{PhD}$ Dissertation thesis, University of Hawaii, Honolulu, 408 pp., 2008.

McNaughton, C. S., Clarke, A. D., Howell, S. G., Pinkerton, M., Anderson, B. E., Thornhill, L., Hudgins, C., Winstead, E., Dibb, J. E., Scheuer, E., and Maring, H.: Results from the DC-8 Inlet Characterization Experiment (DICE): Airborne versus surface sampling of mineral dust and sea salt aerosols, Aerosol Sci. Technol., 41(2), 136-159, doi:10.1080/02786820601118406, 2007.

McNaughton, C. S., Clarke, A. D., Kapustin, V., Shinozuka, Y., Howell, S. G., Anderson, B. E., Winstead, E., Dibb, J., Scheuer, E., Cohen, R. C., Wooldridge, P., Perring, A., Huey, L. G., Kim, S., Jimenez, J. L., Dunlea, E. J., DeCarlo, P. F., Wennberg, P. O., Crounse, J. D., Weinheimer, A. J., and Flocke, F.: Observations of heterogeneous reactions between Asian pollution and mineral dust over the Eastern North Pacific during INTEX-B, Atmos. Chem. Phys., 9, 8283-8308, doi:10.5194/acp-9-8283-2009, 2009.

Menon, S., Koch, D., Beig, G., Sahu, S., Fasullo, J., and Orlikowski, D.: Black carbon aerosols and the third polar ice cap, Atmos. Chem. Phys., 10, 4559-4571, doi:4510.5194/acp-45104559-2010, 2010.

Middlebrook, A. M., Bahreini, R., Brioude, J., Brock, C. A., Cozic, J. A., De Gouw, J. A., Froyd, K. D., Holloway, J. S., Lack, D. A., Lance, S. M., Murphy, D. M., Ryerson, T. B., Schwarz, J. P., Spackman, J. R., Thomson, D. S., Thornberry, T. D., Veres, P., and Warneke, C.: The Influence of Distant Fires on the Chemical Properties of Arctic Aerosol During the Spring of 2008, in 2008 AGU Fall Meeting edited, American Geophysical Union, San Fransisco, California, USA, 2008.

Moteki, N. and Kondo, Y.: Effects of mixing state on black carbon measurement by Laser-Induced Incandescence, Aerosol Sci. Technol., 41, 398-417, doi:10.1080/02786820701199728, 2007.

Moteki, N., Kondo, Y., Miyazaki, Y., Takegawa, N., Komazaki, Y., Kurata, G., Shirai, T., Blake, D. R., Miyakawa, T., and Koike, M.: Evolution of mixing state of black carbon particles: Aircraft measurements over the western Pacific in March 2004, Geophys. Res. Lett., 34, L11803, doi:10.1029/2006GL028943, 2007.

Quinn, P. K., Shaw, G., Andrews, E., Dutton, E. G., Ruoho-Airola, T., and Gong, S. L.: Arctic haze: current trends and knowledge gaps, Tellus B - Chem. Phys. Meteorol., 59(1), 99-114, doi:10.1111/j.1600-0889.2006.00238.x, 2007.

Rogers, D. C., DeMott, P. J., and Kreidenweis, S. M.: Airborne measurements of tropospheric ice-nucleating aerosol particles in the Arctic spring, J. Geophys. Res., 106(D14), 15053-15064, doi:10.1029/2000JD900790, 2001.

Schauer, J. J., Mader, B. T., Deminter, J. T., Heidemann, G., Bae, M. S., Seinfeld, J. H., Flagan, R. C., Cary, R. A., Smith, D., Huebert, B. J., Bertram, T., Howell, S., Kline, J. T., Quinn, P., Bates, T., Turpin, B., Lim, H. J., Yu, J. Z., Yang, H., and Keywood, M. D.: ACE-Asia intercomparison of a thermaloptical method for the determination of particle-phase organic and elemental carbon, Environ. Sci. Technol., 37(5), 993-1001, doi:10.1021/es020622f, 2003.

Scheuer, E., Talbot, R. W., Dibb, J. E., Seid, G. K., DeBell, L., and Lefer, B.: Seasonal distributions of fine aerosol sulfate in the North American Arctic basin during TOPSE, J. Geophys. Res., 108(D4), 8370, doi:10.1029/2001JD001364, 2003.

Schnaiter, M., Gimmler, M., Llamas, I., Linke, C., Jager, C., and Mutschke H.: Strong spectral dependence of light absorption by organic carbon particles formed by propane combustion, Atmos. Chem. Phys., 6, 2981-2990, doi:10.5194/acp-6-2981-2006, 2006.

Schnaiter, M., Linke, C., Mohler, O., Naumann, K. H., Saathoff, H., Wagner, R., Schurath, U., and Wehner, B.: Absorption amplification of black carbon internally mixed secondary organic aerosol, J. Geophys. Res., 110, D19204, doi:10.1029/2005JD006046, 2005.

Schwarz, J. P., Gao, R. S., Fahey, D. W., Thomson, D. S., Watts, L. A., Wilson, J. C., Reeves, J. M., Darbeheshti, M., Baumgardner, D. G., Kok, G. L., Chung, S. H., Schulz, M., Hendricks, J., Lauer, A., Karcher, B., Slowik, J. G., Rosenlof, K. H., Thompson, T. L., Langford, A. O., Loewenstein, M., and Aikin, K. C.: Single-particle measurements of midlatitude black carbon and light-scattering aerosols from the boundary layer to the lower stratosphere, J. Geophys. Res., 111, D16207, doi:10.1029/2006JD007076, 2006.

Sharma, S., Andrews, E., Barrie, L. A., Ogren, J. A., and Lavoue, D.: Variations and sources of the equivalent black carbon in the high Arctic revealed by long-term observations at Alert and Barrow: 1989-2003, J. Geophys. Res.-Atmos., 111(D14), 1-15, D14208, doi:10.1029/2005JD006581, 2006.

Shaw, G. E.: The Arctic Haze Phenomenon, B Am. Meteorol. Soc., 76(12), 2403-2414, doi:10.1175/15200477(1995)076<2403:TAHP>2.0.CO;2, 1995.

Shinozuka, Y., Clarke, A. D., Howell, S. G., Kapustin, V. N., McNaughton, C. S., Zhou, J., and Anderson, B. E.: Aircraft profiles of aerosol microphysics and optical properties over North America: Aerosol optical depth and its association with PM2.5 and water uptake, J. Geophys. Res., 112, D12S20, doi:10.1029/2006JD007918, 2007.

Slowik, J. G., Cross, E. S., Han, J. H., Davidovits, P., Onasch, T. B., Jayne, J. T., Williams, L. R., Canagaratna, M. R., Worsnop, D. R., Chakrabarty, R. K., Moosmuller, H., Arnott, W. P., Schwarz, J. P., Gao, R. S., Fahey, D. W., Kok, G. L., and Petzold, A.: An inter-comparison of instruments measuring black carbon content of soot particles, Aerosol Sci. Technol., 41(3), 295-314, doi:10.1080/02786820701197078, 2007.

Sokolik, I. N. and Toon, O. B.: Direct radiative forcing by anthropogenic airborne mineral aerosols, Nature, 381, 681-683, doi:10.1038/381681a0, 1996.

Solomon, S., Plattner, G. K., Knutti, R., and Friedlingstein, P.: Irreversible climate change due to carbon dioxide emissions, PNAS, 106, 1704-1709, doi:10.1073/pnas.0812721106, 2009.

Spackman, J. R., Gao, R. S., Neff, W. D., Schwarz, J. P., Watts, L. A., Fahey, D. W., Holloway, J. S., Ryerson, T. B., Peischl, J., and Brock, C. A.: Aircraft observations of enhancement and depletion of black carbon mass in the springtime Arctic, Atmos. Chem. Phys., 10, 9667-9680, doi:10.5194/acp-10-9667-2010, 
2010.

Sprung, D., Jost, C., Reiner, T., Hansel, A., and Wisthaler, A.: Acetone and acetonitrile in the tropical Indian Ocean boundary layer and free troposphere: Aircraft-based intercomparison of APCIMS and PTR-MS measurements, J. Geophys. Res., 106(D22), 28511-28527, doi:10.1029/2000JD900599, 2001.

Stephens, M., Turner, N., and Sandberg, J.: Particle identification by Laser Induced Incandescence in a solid state laser cavity, Appl. Opt., 42, 3726-3736, doi:10.1364/AO.42.003726, 2003.

Stocks, B. J., Fosberg, M. A., Lynham, T. J., Mearns, L., Wotton, B. M., Yang, Q., Jin, J. Z., Lawrence, K., Hartley, G. R., Mason, J. A., and McKenney, D. W.: Climate change and forest fire potential in Russian and Canadian boreal forests, Clim. Change, 38(1), 1-13, 1998.

Stohl, A.: Characteristics of atmospheric transport into the Arctic troposphere, J. Geophys. Res.-Atmos., 111(D11), 1-17, D11306, doi:10.1029/2005JD006888, 2006.

Subramanian, R., Roden, C. A., Bopari, P., and Bond, T. C.: Yellow Beads and Missing Particles: Trouble Ahead for Filter-Based Absorption Measurements, Aerosol Sci. Technol., 41, 630-637, doi:10.1080/02786820701344589, 2007.

Subramanian, R., Kok, G. L., Baumgardner, D., Clarke, A., Shinozuka, Y., Campos, T. L., Heizer, C. G., Stephens, B. B., de Foy, B., Voss, P. B., and Zaveri, R. A.: Black carbon over Mexico: the effect of atmospheric transport on mixing state, mass absorption cross-section, and BC/CO ratios, Atmos. Chem. Phys., 10, 219-237, doi:10.5194/acp-10-219-2010, 2010.

Textor, C., Schulz, M., Guibert, S., Kinne, S., Balkanski, Y., Bauer, S., Berntsen, T., Berglen, T., Boucher, O., Chin, M., Dentener, F., Diehl, T., Easter, R., Feichter, H., Fillmore, D., Ghan, S., Ginoux, P., Gong, S., Grini, A., Hendricks, J., Horowitz, L., Huang, P., Isaksen, I., Iversen, I., Kloster, S., Koch, D., Kirkevåg, A., Kristjansson, J. E., Krol, M., Lauer, A., Lamarque, J. F., Liu, X., Montanaro, V., Myhre, G., Penner, J., Pitari, G., Reddy, S., Seland, Ø., Stier, P., Takemura, T., and Tie, X.: Analysis and quantification of the diversities of aerosol life cycles within AeroCom, Atmos. Chem. Phys., 6, 1777-1813, doi:10.5194/acp-61777-2006, 2006.

Tomasi, C., Vitale, V., Lupi, A., Di Carmine, C., Campanelli, M., Herber, A., Treffeisen, R., Stone, R. S., Andrews, E., Sharma, S., Radionov, V. F., von Heyningen-Huene, W., Stebel, K., Hansen, G. H., Myhre, C. L., Wehrli, C., Aaltonen, V., Lihavainen, H., Virkkula, A., Hillamo, R., Strom, J., Toledano, C., Cachorro, V. E., Ortiz, P., de Frutos, A. M., Blindheim, S., Frioud, M., Gausa, M., Zielinski, T., Petelski, T., and Yamanouchi, T.: Aerosol in polar regions: A historical overview based on optical depth and in-situ observations, J. Geophys. Res., 112, D16205, doi:10.1029/2007JD008432, 2007.

Virkkula, A.: Correction of the Calibration of the 3-wavelength Particle Soot Absorption Photometer ( $3 \lambda$ PSAP), Aerosol Sci. Technol., 44(8), 706-712, doi:10.1080/02786826.02782010, 2010.

Virkkula, A., Ahlquist, N. C., Covert, D. S., Arnott, W. P., Sheridan, P. J., Quinn, P. K., and Coffman, D. J.: Modification, Calibration and a Field Test of an Instrument for Measuring Light Absorption by Particles, Aerosol Sci. Technol., 39(1), 68-83, doi:10.1080/027868290901963, 2005.
Warneke, C., De Gouw, J. A., Stohl, A., Cooper, O. R., Goldan, P. D., Kuster, W. C., Holloway, J. S., Williams, E. J., Lerner, B. M., McKeen, S. A., Trainer, M., Fehsenfeld, F. C., Atlas, E. L., Donnelly, S. G., Stroud, V., Lueb, A., and Kato, S.: Biomass burning and anthropogenic sources of $\mathrm{CO}$ over New England in summer 2004, J. Geophys. Res., 111, D23S15, doi:10.1029/2005JD006878, 2006.

Warneke, C., Bahreini, R., Brioude, J., Brock, C. A., De Gouw, J. A., Fahey, D. W., Froyd, K. D., Holloway, J. S., Middlebrook, A., Miller, L., Montzka, S., Murphy, D. M., Peischl, J., Ryerson, T. B., Schwarz, J. P., Spackman, J. R. and Veres, P.: Biomass burning in Siberia and Kazakhstan as an important source for haze over the Alaskan Arctic in April 2008, Geophys. Res. Lett., 36, L02813, doi:10.1029/2008GL036194, 2009.

Warneke, C., Froyd, K. D., Brioude, J., Bahreini, R., Brock, C. A., Cozic, J., De Gouw, J. A., Fahey, D. W., Ferrare, R., Holloway, J. S., Middlebrook, A. M., Miller, L., Montzka, S., Schwarz, J. P., Sodemann, H., Spackman, J. R., and Stohl, A.: An important contribution to sprintime Arctic aerosol from biomass burning in Russia, Geophys. Res. Lett., 37, L01801, doi:10.1029/2009GL041816, 2010.

Westerling, A. L., Hidalgo, H. G., Cayan, D. R., and Swetnam, T. W.: Warming and Earlier Spring Increase Western US Forest Wildfire Activity, Science, 313, 940-943, doi:10.1126/science.1128834, 2006.

Wilson, J. C., Lafleur, B., Hilvert, G. H., Seabaugh, W. R., Fox, W. J., Brock, C. A., Huebert, B. J., Geseler, D. R., Muller, J., and Reeves, J. M.: Function and performance of a low turbulence inlet for sampling super-micron particles from aircraft platforms, Aerosol Sci. Technol., 38, 790-802, doi:10.1080/027868290500841, 2004.

Xu, B., Cao, J. J., Hansen, J., Yao, T., Joswia, D. R., Wang, N., Wu, G., Wang, M., Zhao, H., Yang, W., Liu, X., and He, J.: Black soot and the survival of Tibetan glaciers, Proc. Natl. Acad. Sci. USA, 106(52), 22114-22118, doi:10.21073/pnas.0910444106, 2009.

Yamanouchi, T., Treffeisen, R., Herber, A., Shiobara, M., Yamagata, S., Hara, K., Sato, K., Yabuki, M., Tomikawa, Y., Rinke, A., Neuber, R., Schumachter, R., Kriews, M., Strom, J., Schrems, O., and Gernandt, H.: Arctic Study of Tropospheric Aerosol and Radiation (ASTAR) 2000: Arctic haze case study, Tellus B - Chem. Phys. Meteorol., 57(2), 141-152, doi:10.1111/j.16000889.2005.00140.x, 2005.

Yang, M.: Separation of light absorption to black carbon, brown carbon, and mineral dust - interpretations of atmospheric measurements near Beijing, MS Thesis, University of Hawaii at Manoa, Honolulu, Hawaii, USA, 2007.

Yang, M., Howell, S. G., Zhuang, J., and Huebert, B. J.: Attribution of aerosol light absorption to black carbon, brown carbon, and dust in China - interpretations of atmospheric measurements during EAST-AIRE, Atmos. Chem. Phys., 9, 2035-2050, doi:10.5194/acp-2035-2009, 2009. 